University of Rhode Island

DigitalCommons@URI

Open Access Master's Theses

1991

\title{
THE TEXTILE FINISHING INDUSTRY IN NEW ENGLAND: IS FLEXIBLE SPECIALIZATION OCCURRING?
}

Alison K. Nisbet

University of Rhode Island

Follow this and additional works at: https://digitalcommons.uri.edu/theses

\section{Recommended Citation}

Nisbet, Alison K., "THE TEXTILE FINISHING INDUSTRY IN NEW ENGLAND: IS FLEXIBLE SPECIALIZATION OCCURRING?" (1991). Open Access Master's Theses. Paper 565.

https://digitalcommons.uri.edu/theses/565

This Thesis is brought to you for free and open access by DigitalCommons@URI. It has been accepted for inclusion in Open Access Master's Theses by an authorized administrator of DigitalCommons@URI. For more information, please contact digitalcommons-group@uri.edu. 
THE TEXTILE FINISHING INDUSTRY IN NEW ENGLAND:

IS FIEXIBLE SPECIALIZATION OCCURRING?

BY

ALISON $K$. NISBET

A RESEARCH PROJECT SUBMITTED IN

PARTIAL FULFILIMENT OF THE REQUIREMENTS

FOR THE DEGREE OF MASTER OF COMMUNITY PIANNING

UNIVERSITY OF RHODE ISLAND

1991 


\section{MASTER OF COMMUNITY PLANNING}

RESEARCH PROJECT OF

ALISON K. NISBET

APPROVED :

Major Professor

ACKNOWLEDGED :

Director

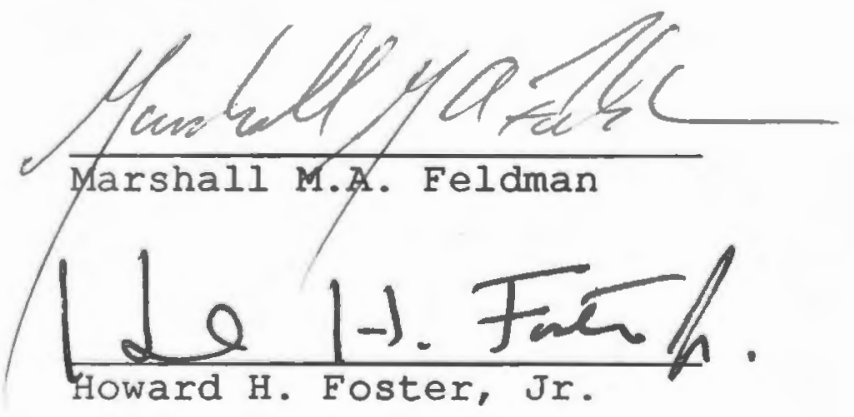




\section{ABSTRACT}

This project is an in-depth study of flexible manufacturing in the New England textile finishing industry.

Chapter 1 represents a literature review of the current debate surrounding the flexibility issue.

Chapter 2 provides a brief outline of the methodology of the project.

Chapter 3 provides a history of the textile industry, both in New England, and the United States as a whole.

Chapter 4 zones in specifically on the textile finishing industry. It describes the production processes involved in finishing, and gives figures for employment within the industry at the national level. This chapter also identifies the ten key SIC codes that make up the finishing industry.

Chapter 5 looks at industrial organization. It provides general information about the impact of imports on the industry as a whole, and the implications that this has for textile finishing. Further, it addresses the issues of profitability, productivity, supplier-customer relations, and firm size within the finishing industry.

Chapter 6 addresses the issue of whether flexibility is increasing in textile finishing in New England.

Chapter 7 provides a summary of the industry interviews that the study team for this project has undertaken at the 


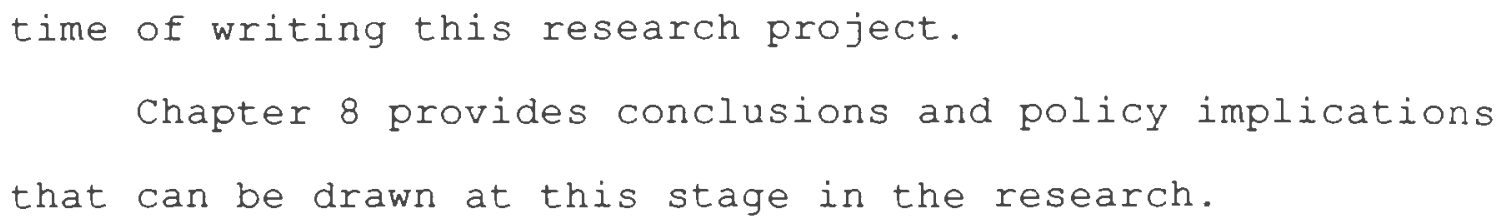




\section{ACRNOWLEDGEMENTS}

I would like to thank Dr. Marshall Feldman, Assistant Professor, Department of Community Planning, for giving me the opportunity to work on this project, and for his patience and reassurance in my moments of confusion.

I would like to thank Dr. Richard McIntyre, Department of Economics, and Dr. Marcia Feld, Department of Community Planning, for all their help as readers for this research project.

I would like to thank my Mother and Father, who, though they were three thousand miles away when I wrote this, were the ones who encouraged me as a child to get this far. Finally, I would like to thank Michael for making my time in the United States really worth it. 
TABIE OF CONTENTS

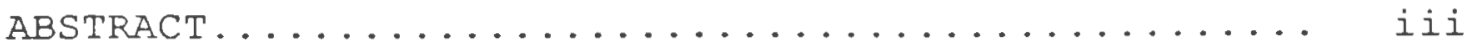

ACKNOWLEDGEMENTS ..................... v

TABLE OF CONTENTS..................... vi

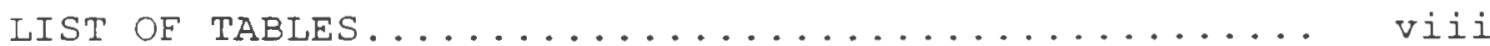

Chapters

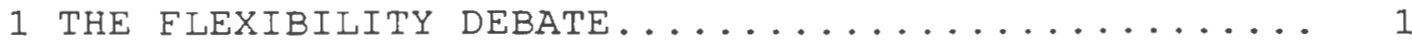

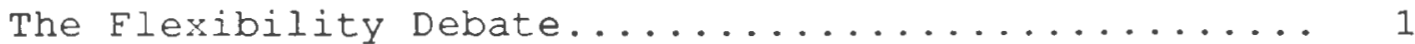

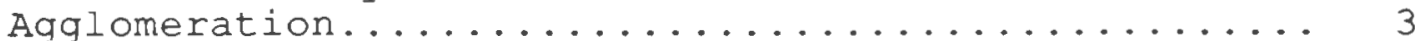

Adaptations to the Flexibility Theory............ 6

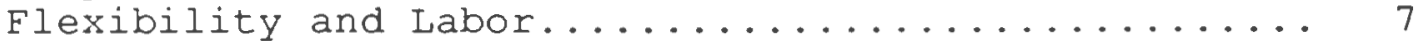

Flexibility and Regional Economies.............. 8

Alternative Models of Industrial

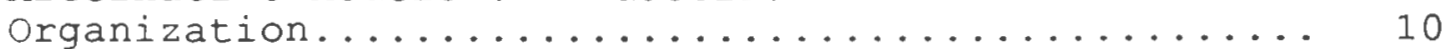

Flexible Specialization and the Textile Industry... 18

2 METHODOLOGY......................... 21

3 HISTORY OF THE TEXTILE INDUSTRY.............. 23

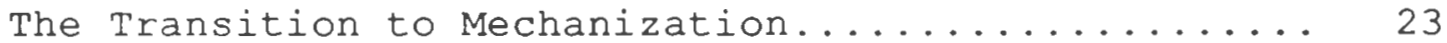

The Shift of Textiles to the South.............. 28

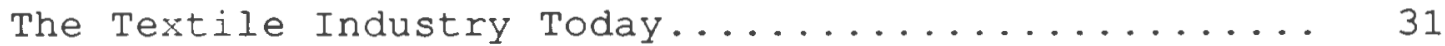

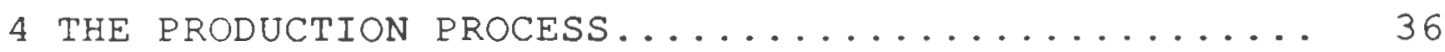

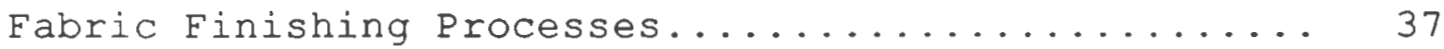

Textile Finishing SIC Codes.................. 41

Total Employment in Textile Finishing........... 43

5 INDUSTRIAL ORGANIZATION................. 49

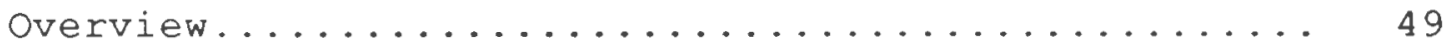

Employment Trends in the Textile Industry......... 49

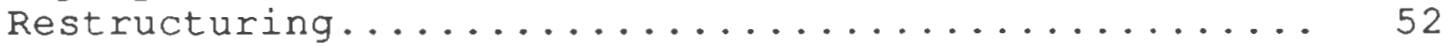

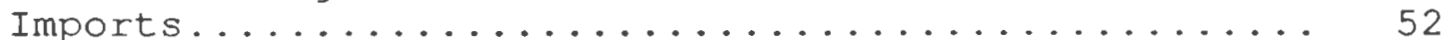

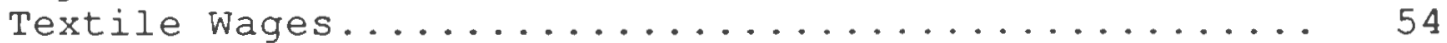

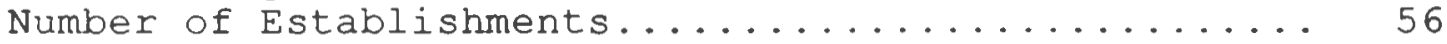

State of the Industry.................. 56

6 IS FLEXIBILITY INCREASING?................ 59

Flexibility and the Textile Finishing Industry in

New England.......................... 60

The Blurring of the Lines Between Mass Production

and Flexible Specialization.................. 61

Textile Finishing in New England.............. 63 


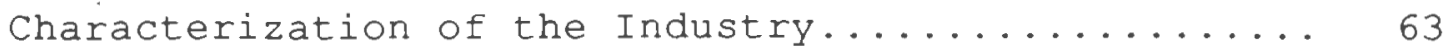

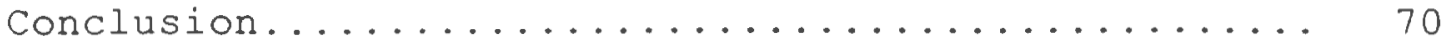

7 FINDINGS OF THE INDUSTRY INTERVIEWS........... 71

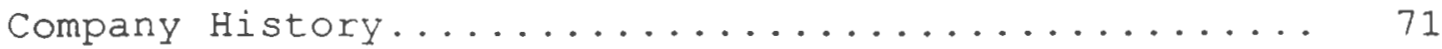

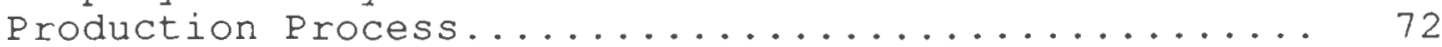

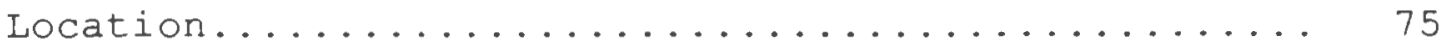

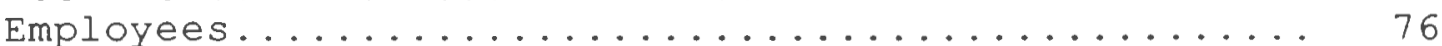

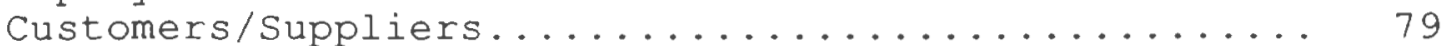

Future of the Industry and Imports............. 80

8 CONCLUSIONS AND POLICY IMPLICATIONS ............ 82

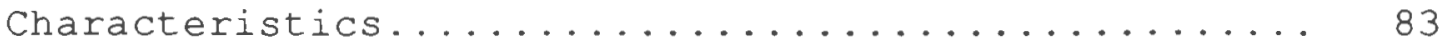

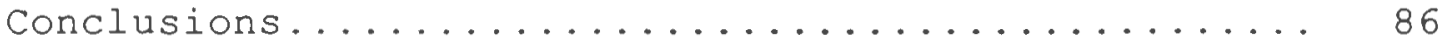

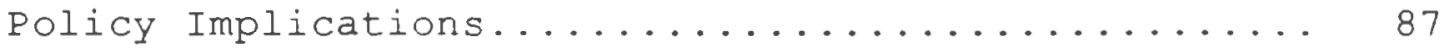

Implications for Community Planning............ 88

BIBLIOGRAP HY 


\section{LIST OF TABLES}

Table 1 Value of Regional Cotton Textile Output.... 30

Table 2 Trade Data: Textile Mill Products........ 33

Table 3 Total Textile Finishing Employment as a

\% of Total Manufacturing Employment....... 45

Table 4 Textile Finishing Total Employment by SIC... 48

Table 5 Imports and Exports of Textiles.......... 50

Table 6 Textile Industry wages and Employment..... 55

Table 7 Number of Establishments in Finishing..... 57

Table 8 Trade Data for 1972-1985........... 66

Table 9 Total Numbers Employed in Textile

Finishing for the United States, $1987 \ldots . .668$ 
CHAPTER 1

THE FLEXIBILITY DEBATE

The world we find ourselves in today is very different from that of the immediate post-war period. Economic downturns seem no longer to be short pauses in the progression to greater affluence. Rather, these downturns seem to pose a real threat to the economic system on which post-war growth is based. Piore and Sabel (1984) assert that the present deterioration in economic performance results from the limits of the model of industrial development founded on mass production. ${ }^{1}$ Piore and Sabel question the viability of large, vertically integrated firms engaged in mass production, that once characterized an unprecedented period of growth, and suggest that today the most successful industries are increasingly characterized by "flexible specialization", a term indicating spatially dense networks of relatively small, vertically disintegrated firms.

\section{The Flexibility Debate}

Support for this hypothesis has been mixed. Some empirical studies strongly support the claims made by Piore and sabel (1984), while others have found alternative forms

1 Mass production is defined as the use of special-purpose (product specific) machines and of semiskilled workers to produce large quantities of standardized goods. 
of industrial organization are in fact becoming important. This chapter will review these divergent perspectives.

Feldman and Yuan (1990:2) point to the fact that the debate over flexibility is more and more being placed on theoretical ground demarcated by the French "Regulation school" of political economy. In this approach, periods of stable growth in capitalist economies require a wide variety of non-market institutions, norms, and practices. These historical entities collectively constitute an "accumulation regime", determine the system's characteristics functioning, or "mode of regulation." They note that if it were not situated in this context, much debate over flexibility would not exist.

At one end of the spectrum, Piore and sabel lay out the concept of flexible specialization and offer it as the more viable of two alternatives, the other being multinational Keynesianism. They do not, however, overlook its problems. For example, they note the difficulties of envisaging a flexible economy that is successful, as there is no model on which to build such a notion, and this would require what they refer to as an exercise of the imagination. Piore and sabel offer four types of flexible specialization. The first is regional conglomerations. Under this category they offer the examples of specialized districts of northern and central Italy, the New York garment district, and the construction industry in most 
cities in the United States.

This model is characterized by no one of the firms being dominant, and contracts or arrangements between firms are short-term, with the roles played by the various parties constantly changing. In this situation there are institutions that act to assist in the recombination and coordination of the production process. No one firm links all processes of production. Rather, cohesion rests on a strong community sense among the collected firms.

The second type of flexible specialization is federated enterprises. This form is associated with the "systeme Motte" and Japanese companies. Here the "federated enterprises hold one another's stocks and have interlocking boards of directors." (Piore, Sabel, 1984) The firm is not organized under an hierarchy structure, as with the mass production system.

The third and fourth forms of flexible specialization are the firm with the solar-system model of orbiting suppliers and its close cousin, the workshop factory. Such firms are organized in nineteenth century style workshops.

\section{Agglomeration}

Scott (1988) takes the concept of flexible specialization and adds a new dimension, that of agglomeration. Agglomeration is the process whereby vertically disintegrated firms cluster together to increase 
their combined total volume. Localization economies are achieved for all firms in a single industry at a single location, consequent upon the enlargement of the total output of that industry at that location.

Scott observes that by the 1970s, in the face of the deepening unworkability of the fordist regime the governments of countries in North America and Western Europe started to dismantle the welfare-statist arrangements that had helped to regulate it but were now only becoming an additional element of the overall crisis.

As this one regime of accumulation began to collapse, in the vacuum that was created, another was beginning to take shape. In particular, scott refers to the emergence of a number of new flexible forms of productive activity. He believes these are concentrated in three groups of industrial sectors: revivified artisanal and designintensive industries producing outputs largely but not exclusively for final consumption, high technology industries and their associated group of input suppliers and dependent subcontractors, and service functions, especially business services (Scott, 1988:175).

Scott takes Piore and Sabel's theory one step further by grafting the concept of agglomeration onto the flexible specialization hypothesis. He suggests that with the process of vertical disintegration symptomatic of flexible specialization, comes a "countervailing disadvantage" in the 
rise of certain kinds of costs. These he identifies as the direct expenses of transport, communication, information exchange, search, and scanning.

Scott sees evidence of this new industrial form taking shape in two specific areas. The first of is the inner-city areas where there are older manufacturing based industries. He believes evidence points to the reemergence here of the old craft form of production in for example, clothing, furniture and the film industry in Los Angeles. He believes that suburban extensions are also included, the classic example being Route 128 outside of Boston. Scott observes that in areas such as route 128 employers deliberately exclude the traditional male workforce and instead seek out females and recent immigrants for production jobs.

The second area scott identifies is the sunbelt and what he refers to as the third development zones of North America and Western Europe. These areas have been typically characterized as being peripheral to the old core regions of Fordist industries. Their economies have been largely composed of agriculture, trade and small-scale industry, with urban settlement being limited until recent times. These peripheral and semi-peripheral areas are, according to Scott, now constituting many of the new industrial spaces. scott points to the example of the "Third Italy". This area has grown over the last three decades with industries 
that are highly flexible. This growth is particularly significant when one considers that this part of Italy lay on the periphery in the days of mass production.

Other examples offered by scott include high tech areas which are thriving in such isolated areas as Cambridge, England and Grenoble, France. Scott contends that establishments in these areas, like those in the Third Italy, rely on small interlinked establishments.

\section{Adaptations of the Flexibility Theory}

Storper (1989) addresses the generality of the issue of flexible specialization. He poses the question of whether places as different as Silicon Valley in California and the New York City garment district can realistically be examples of the same phenomenon or whether the debate has created what he refers to as a "chaotic conception". He asserts that the different examples of flexible specialization have different roots, but that this does not lead to the conclusion that they are isolated local

occurrences bearing no resemblance to each other. Storper takes up the question of whether or not flexible specialization methods are becoming dominant. He acknowledges the critics who cite the example that even in industries where flexible specialization does occur, there is still a large amount of mass production involved. He identifies the divide in opinion between those who persist 
in looking at technologies and production units only, in contrast to those who look at technologies in organizational context and units in the context of production systems.

Storper believes that what must be done to make a valid argument that a new, general period of capitalist economic development is occurring is to take what he refers to as the

"hard cases" which are the large, complex products in capital-intensive industries. Storper goes on to use the illustration of a study undertaken of the automobile industry in France. Amidst claims that the industry was actually a more automated form of mass production, he actually found a form of mass production operating alongside production units that were internally flexible. He further asserts that system logics are increasingly those of flexibility.

\section{Flexibility and Labor}

Schoenberger (1988b) accepts much of the theoretical underpinning of the flexibility theory, but questions the bright reality portrayed by its exponents. She points to the fact that flexible specialization promises little for those workers who have borne the brunt of industrial restructuring. She goes on to observe that those who survive the transition will have less to look forward to than under mass production. There may be gains in job stability and union relations, as flexibility requires more 
participation of workers than was needed under fordism. Schoenberger also sees flexible specialization as demanding extremely flexible work schedules, for example the growth of part-time work is seen as increasing flexibility.

The problems with this new organizational structure are not limited to the lower ranks of the workforce. With workers on the shop-floor having been made redundant, upper-echelon workers will increasingly become the major labor-cost concern for the firm. Further, with increasing pressure to reduce the cycle time from design to manufacturing, efforts will move apace to standardize and automate design and programming tasks.

Mass production was based on the broad expansion of incomes, yet writers have observed that flexible specialization has been characterized by a social polarization of incomes. In addition, to this phenomenon of few rich people keeping the economy going, support from the welfare state to the poor is increasingly being withdrawn.

Schoenberger concludes that the transition to a flexible mode of accumulation will be fraught with troubles of its own. Indeed, the result may well be a crisis of effective demand.

\section{Flexibility and Regional Economies}

Sabel (1988) argues that until the mid-nineteenth century the region was the unit of economic activity. He 
asserts that regions such as Sheffield, England, were both flexible and specialized. By the 1960 s the giant corporation had replaced the region as being the main unit of economic activity, and with this organizational shift came all the traits of mass production. However, by the 1970s, when international competition rose, and world markets began to fragment, the same firms that had adopted mass production methods, became wary of investment in product-specific machinery due to the vulnerability of markets and rapidly changing demand. In response to this volatility, firms increasingly experimented with flexible organizational forms, which allowed for a more rapid response. Sabel asserts that this move to more flexible responses has led to the reconsolidation of the region as an integrated unit of production.

Sabel identifies four developments that have contributed to this process. First he sees the emergence of prosperous modern day versions of industrial districts in Western Europe and North America. Second, Sabel points to the reorganization of the large multinational corporation and the rise of subcontracting. Third, sabel points to the transformation of local governments from performing a welfare role, to performing the role of job-creation agencies. Finally sabel notes that trade unions are cooperating in industrial reorganization.

Sabel also sees several problems. Even if regional 
economies do emerge, they are unlikely to survive without the aid of national institutions, still undefined. Flexibly specialized firms may be better able to survive economic turbulence than mass production firms are. This does not make them immune to failure. Crisis regions must be assisted by buoyant areas if they are to survive. If this is to be successfully achieved a new national system of resource allocation may need to be created.

\section{Alternative Models of Industrial Organization}

Donaghu and Barff (1990) argue that they have found an alternative to flexible specialization. They argue that Nike's production system represents an alternative postFordist form of industrial organization to manufacturing based on flexible specialization.

Donaghu and Barff (1990) show, "that within Nike, inflexible means of production coexist with highly flexible and dynamic forms of company organization." One of the main focuses of the paper concerns Nike's subcontracting relations; Nike subcontracts $100 \%$ of it's athletic footwear production.

Nike uses three main strategies to promote its subcontracting relationships. These techniques are used to encourage and secure stability and trust in relationships with subcontractors. First, Nike operates what it refers to as an "expatriate program" where Nike expatriate technicians 
become permanent personnel in the factory producing Nike footwear. The rationale is that their presence helps to insure a smooth product development process and maintain quality control. Second, Nike encourages its partners to participate in joint product development activities. These close ties to keep Nike's production partners up to date with the directions Nike plans to take in the marketplace. Third, with factories that only manufacture Nike products, the company places orders once a month, thus avoiding production varying by more than 20 percent each month. This acts as a stabilizer on production for factories that have been with Nike for many years as well as those that are newer.

The second focus of the paper supplements Schoenberger's work (1988a), that of a critical evaluation of the "New International Division of Labor" model.

According to Donaghu and Barff, (1990:3)

Nike's organization of production is influenced by the attraction of low-wage labor in the periphery and only marginally by the market potential such locations hold. The geography of the Nike production system however, is also determined by the nature and the stability of the long term partnerships it has established with its producers. Since 1980, Nike's manufacturing organization has become progressively reconcentrated in South East Asia.

In terms of flexibility in machinery, the only elements of Nike's machinery found to be flexible is the computeraided design, computer-aided engineering, and some of the numerically controlled machines used by several South Korean 
subcontractors. Thus the authors draw the conclusion that machinery within the firm must be considered inflexible.

Donaghu and Barff see labor at Nike as numerically rather than functionally flexible. Numerical flexibility is the propensity of firms to adjust the quantity of labor used in production. Functional flexibility is the case in which production workers are responsible for not only manufacturing but also process innovation, training, meeting with customers, and maintaining equipment.

Nike has a history of shifting production between regions and countries. Further, it uses capacity subcontracting to meet changing market demand. Nike produces footwear with mass production methods, but it also relies on extensive subcontracting networks. Donaghu and Barff note that Gertler (1988), Cooke (1988), Holmes (1988), and Anderson and Holmes (1989) have pointed out with reference to the automative industry, flexible production systems of subcontracting rely upon close communication, reliability, trust, and precise timing.

Cooke (1988) lists specific criteria for an industry to be flexibly integrated:

internal integration of marketing, production, and $R \& D$ and the integration of product and process innovation; the use of flexible machines; the pursuit of economies of scope, internally, by multiple production, and externally, via strategic alliances; diagonally integrated interfirm relationships, wherein specialized production takes place in-house and routine production is subcontracted; an occupational structure on a 
multiskilled group of engineers and nonspecialist workers in a core (i.e. functional flexibility) augmented by a casual, (numerically flexible) peripheral, workforce.

Donaghu and Barff assert that with the exception of the second criterion, Nike closely coincides with cooke's definition. They also observe however, that if they take Schoenberger's point that not every factor in a production system must convert to a new and discernible form, then Nike could be perceived as flexible. But if the move to flexibility is a process in which the core of the transformation is in the workplace, then Nike's industrial organization cannot be thought of as flexible.

In conclusion, Nike is fundamentally different from the mass production firms of the past. Nike is demand-driven, while mass production firms under Fordism were supplydriven. But Nike cannot be characterized as flexibly specialized.

Sayer (1988) argues regardless of the state of mass production in the West, it is still widely in use in Japan. Sayer takes on two main themes: first, he questions the concepts of fordism and the crisis of fordism on which the debate about postfordism centers. Second, he addresses the issue of how Japan's apparently rigid industrial organization gives it significant advantages over less organized western capital.

He disputes that fordism is the cause of capitalism's 
crisis. Further, he doubts some of the alleged limitations of mass production. He does not see fordism as inevitably causing worsening conditions for workers, and this in turn generating poor labor relations.

With regard to the Japanese experience, Sayer observes that some of the tendencies resemble those of flexible specialization, while others overtly contradict it. Sayer points to the rigidities of the Japanese system, which include obligated trading relationships, lifetime employment, and seniority based payment schemes, all of which stand in stark contradiction to a seemingly flexible system. Sayer argues that while some components of Japanese industry do have flexible traits (eg lifetime employment, but regular job shifting within the company), they also have many inflexible traits that seriously contradict the flexible specialization theory. He also calls into question:

the central contrast between the alleged decline of mass production and the rise of small-batch production, and the implicit associations between vertical integration and mass production. (Sayer, 1988 )

Sayer concludes that superior economic performance by the Japanese and Germans over the United States and Britain has less to do with the choice of flexible specialization above mass production and more to do with broader environmental characteristics that cut across labor processes and froduction scale distinctions. 
Markusen (1991) attempts to answer two basic questions: how did the technologies so key to the new regimes and to flexible specialization come to be in the first place, and why do particular places become the loci of new spatial industrial complexes built around these technologies.

Markusen notes that there is increasing evidence that elite, white male jobs are the only ones prospering under the new emerging system, but little has improved for average workers, who is just as impacted by economic restructuring.

Markusen contends that so long as the literature continues to highlight the cases that have triumphed over others without asking the question why this has occurred, little will be learnt, and other locations attempting to replicate the experience of the success stories will be unable to do so. Further, Markusen asserts that so long as the State is excluded from the analysis, no acceptable interpretation of technological evolution or the emergence of new industrial spaces can be constructed.

Markusen argues that such areas as Route 128 in Massachusetts and Silicon Valley in California are new industrial districts, but the reason for this is not because they are natural "windows of opportunity", or the result of some "exogenous technological leap". Rather, they are a result of state sponsorship of particular industries and technologies in the pursuit of the cold war and its military 
objectives. She believes these new industrial districts cannot continue to grow based on their own endogenous growth through economies of scope, vertical disintegration and what she calls "networks of cooperative innovation." Markusen believes their future rests in the hands of the state, and its decisions that affect where monies for $R$ \& $D$ are located.

Gertler (1988) views the claim that we are experiencing a fundamental break from the past with skepticism. He argues that flexible technologies have been with us since the industrial revolution. He offers the example of the screwdriver, which can be viewed as a fixed piece of capital and that is infinitely flexible in its range of applications. The difference between this basic type of flexible machinery and what we know today as flexible is that in the old flexibility humans had to operate and continually monitor the machine.

Gertler (1988) observes that Hirschhorn (1984), Noble (1984), and Ayres (1986) all verify the early origins of numerical control and computerized numerical control technology dating back to the beginning of the Fordist era. Their work suggests it is more appropriate to view today's flexible technologies as the result of a long, uninterrupted chain of innovations rather than a clean break with the past, despite improvements over earlier versions. He further argues that some of the motivations that have led to 
the adoption of flexible systems are not new, but actually date back to the beginning of organized production.

Amin (1989) is also skeptical as to the validity of the flexible specialization theory. He points to the lack of attention paid to the widespread usage of batch and craft production under the Fordist regime. Amin also notes Williams et al (1987:405-439) point out that mass producers have been able to adapt to cope with greater consumer demand for differentiated goods. Amin goes on to quote solo (1985) who observes that:

No matter how flexible specialization is, it cannot wriggle out from the descending force of a decline in aggregate demand... Nor would future uncertainty be less debilitating for the flexible specialization technology than for that of mass production.

Amin highlights, as have others, the evidence of little job and wage security, poor pay, and reduced formal protection of basic rights. He also argues that sabel underplays the existence of differences in the characteristics and origins of various contemporary industrial districts, such as the key importance of large retailers and subcontractors as key actors in some areas, small firm networks in other areas, or even government expenditure especially in the defense sector, elsewhere (Amin et al 1986; Markusen 1991).

The main thrust of Amin's paper is an analysis of whether firms in the "Third Italy" are flexible. As a 
result of his analysis he concludes there are severe problems with the flexibility thesis as defined by Piore and Sabel. He notes that in the "Third Italy":

very few, and only the oldest of the industrial districts come close to resembling the "ideal type". The organizational structure in these areas appears to be changing, with new forces favoring industrial concentration emerging. Despite what Piore and Sabel claim to have found, some of the key elements of the successful industrial district are highly place specific.

\section{Flexible Specialization and the Textile Industry}

Piore and sabel use the textile industry in what has the "Third Italy" as one of their key examples of the reemergence of craft principles, which led them to hypothesize about the emergence of flexible specialization on a more universal scale. Because much of the flexibility argument was based on the assertion that the phenomenon was occurring in the industrial districts in Italy, writers have returned to take a second look at the Third Italy.

Amin (1989) examined the Third Italy in light of the claims made by Piore and Sable (1984). He observes the rise in the number of small firms located in the region, observing the consensus that the initial rise in this number came about as a result of the extensive use of subcontracting by both medium and large firms in the area. The combined growth of this sector, however, was attributed to the small firms ability to free themselves of the subcontracting relationships and sell specialist goods and 
services in the market and to other specialist buyers.

Amin notes that official statistics show a poorer level of innovation among small firms than their larger counterparts. They also show, conversely, that this lower innovative level does not translate into lower profits.

Smaller firms experienced lower wages and longer working hours, with lack of industry regulation to establish minimum working standards.

Amin argues that it may well be true that the classic portrayal of the flexibly specialized district exists only in the industrial district of Italy that Piore and Sabel originally used to support their theory. Textile production in Prato may be flexibly specialized in the Third Italy, and it works there. However, one cannot, it seems, take that argument with the unique set of conditions found in the Third Italy and apply it universally to textiles or any other industry.

A consensus of opinion has not yet emerged from the flexibility debate. This chapter has highlighted the main areas of discussion in the debate. The current literature is not comprehensive in addressing all dimensions of flexible specialization. In particular, the debate has not thoroughly addressed aspects of flexibility which apply to the textile finishing industry. Walker (1990) has begun to address aspects of the flexibility debate that are applicable to the textile finishing industry, but the 
argument has not yet been developed far enough. This problem will be addressed in chapter 6 . 


\section{CHAPTER 2}

\section{METHODOLOGY}

One of the major problems with prior studies of flexible production is that they overwhelmingly rely on case studies, but little, if any systematic selection process was used to pick the industry. This study however, came about as the result of a systematic selection process.

In the first phase of the project, national data were analyzed to identify industries in which flexibility and vertical disintegration seemed to be increasing. The data for this procedure came from the U.S. Small Business Administration's Small Business Data Base (SBDB) for the years 1976-1984. These data were used to construct the following indicators:

* The number of specialist independent establishments ${ }^{2}$

* Employment per establishment

* Total employment

* National firms as a proportion of all firms ${ }^{3}$

Changes in these indicators over the years 1976-1984 were also computed using a regression-residential approach

2 An establishment is considered "independent" if it is the only establishment in its firm; a "specialist" is a firm whose parent enterprise does business in a single 4-digit standard Industrial Classification (SIC) category.

3 A national firm is a firm with branches in two or more regions of the country. 
(Milier; Feldman, 1990).

The combination of these indicators identified which industries (analyzed at the four-digit SIC code level) appeared to be experiencing trends that implied increasing vertical disintegration and flexibility.

Based on analysis these indicators, textile finishing, aircraft parts, and medical and surgical instruments were selected for in-depth study.

The next phase encompassed the use of secondary sources on the industry, face-to-face interviews with firms in the industry, and a mail survey. ${ }^{4}$ Secondary sources consulted included the Census of Manufactures, The Directory of New England Manufacturers, Standard and Poor's Industry Surveys, County Business Patterns, technical texts describing the process of textile finishing, and academic literature on the industry. Interviews were conducted at three Rhode Island textile finishing firms using a predetermined format. The firms were asked questions pertaining to the company's history, production process, location, employees, customer/supplier relations, and perceptions of the future of the industry and the impact of imports on the industry.

The final phase of the project involved use of the data and information collected to provide a detailed analysis of the industry. This information will be used to check the validity of the original estimates of national trends.

4 The Survey is not yet completed as of this date. 


\section{CHAPTER 3 \\ HISTORY OF THE TEXTILE INDUSTRY}

Several driving forces made New England the original location for textile manufacturing in the United States. Burgy (1932:4) observes that the cotton-mill landscape reflects the stream network and the coastal bounds of the region, geographical determinants which operated in a more or less contemporaneous fashion as the industry developed. The necessity of water power for the successful operation of Arkwright machinery, such as slater designed and used in his first mill on the banks of the Blackstone River in Rhode Island, limited the earliest mills to vantage points on stream courses. This explains the general mill distribution and the individual mill clusters up to 1850.

\section{The Transition to Mechanization}

During the colonial period, the textile industry remained essentially a craft industry. The transition to mechanization began in 1790, when the firm of Almy and Brown, tapping into the technical innovations of Samuel Slater, spun cotton yarn with water-powered machinery. This led to the factory system of production being introduced. Kennedy (1936) observes that from 1790, when Samuel slater built at Pawtucket, Rhode Island, the first spinning machinery utilizing water power along the lines of 
Arkwright's machines, to 1804, only sixteen cotton mills had been established in the United States. By 1810 this number had increased to 269, with 87,000 spindles, and by 1815 the number of spindles had been increased to 130,000 .

The transition to power-driven machinery was almost complete by 1830, when all but two processes in cloth manufacturing were mechanized. From 1830 up to the Civil War, the New England textile industry grew, and enjoyed almost unchallenged domestic prosperity. Kennedy points out that the most significant event during this period in the textile industry was the organization of the Boston Manufacturing Company at Waltham, Massachusetts. This company was formed under the stimulus of the Civil war (Gordon et al, 1982). As kennedy observes, the launching of this mill was, in many ways, to shape the course of how the industry would develop in at least four respects. According to Kennedy these were: the integration of power-driven spinning and weaving machinery within the same plant (spatial integration), the financing of a large-scale enterprise by the formation of a joint stock company and the sale of common stock, the employment of an independent selling house to distribute the product of the mill, and establishment of a separate textile machine industry. The Waltham system differed from the Rhode Island system. Under the Rhode Island structure, integration ran throughout the process from spinning machines to spinning to financing. 
Weaving machines, weaving and finance were also integrated with distribution. This stands in contrast to the waltham situation where spinning and weaving machines were disintegrated from spinning and weaving operations. The distribution process was also disintegrated. Financing under the waltham system was partially disintegrated.

Up to 1850, labor for the mills came predominantly from New England farms. Mill owners lured farmers and their children, notably their daughters, into the mills, but many returned to farming after they had earned enough money to buy land. This was the case with much of the mill workforce around Lowell, Massachusetts, this being the single most important town in firms of textiles, in the country, meaning that there was no permanent mill population north of Boston. In terms of the accommodations that mill workers occupied, it was a common practice in towns with less than 10,000 persons to find that the mill company would own a sizeable amount of the housing stock within the town. In 1924, for example, 62 out of 187 of the cotton-textile concerns in Massachusetts owned or controlled company houses (Burgy, 1932:153). However, this tendency was to change with improved transportation facilities in the form of better roads and automobiles, making for an increase in the independence and mobility of the mill worker. This factor led to a change in the relationship between management and worker due to the decreased reliance on the part of the 
worker on management for housing.

The invention of the Draper automatic loom in 1895 and its distribution after 1900 had a very profound impact on the direction that the industry took for the following half century. Named after its inventor, this piece of machinery allowed for the changing of the bobbin without stopping the loom, the shuttle being refilled automatically with a fresh bobbin from a magazine on one side of the loom (Kennedy, 1936:8). Development of the Draper loom coincided with a period of "easy" money in the financial markets, as interest in industrial promotions intensified. The result of this coincidence was the greatest expansion of the textile industry in its history, driven mainly by the prospect of higher profits in companies equipped with the Draper loom. Despite this rise in the desire to invest in textile companies due to rising profits from technical innovation, relative to other industrial ventures, textiles remained relatively unimportant, in terms of investment, because of the small size of the majority of the firms within the industry. Kennedy notes that as a result of this, it (textiles) was unable to command attention for its securities in the principal capital markets of the country. Although this situation was a hindrance to widespread ownership of securities, it did not prevent the flow of capital into the industry, through stocks, which for years had been well known for it's earnings. It was under such 
conditions that the two large cotton mill consolidations of the trust era were formed, the duck merger, originally known as the Mount Vernon-Woodberry Cotton Duck Company, and later as the Consolidated Cotton Duck Company, and the New England Cotton Yarn Company (Kennedy, 1936:12).

In 1913, Lockwood Greene and Company, a firm of textile engineers that was undertaking much of the building of new mills at the time, took over management of the discredited cotton duck merger to undertake the reorganization of the company and run the mills. At the time this company was known as the International Cotton Mills (New York), and was the outcome of several successive reorganizations of what, in 1899, when first formed, was known as the Mount VernonWoodberry Cotton Duck Company. The original consolidation had been undertaken at the height of the trust forming era by an organization of promoters who anticipated making large profits from the formation of a monopoly of mills producing cotton duck and related fabrics and the resulting sales of securities from the company. For a short period the consolidated company undertook to buy out its competitors, but this led it into financial problems which, despite several attempts at reorganization, grew worse. This was when Lockwood Greene stepped in to take over the ailing firm. For its part in the reorganization of the firm, Lockwood Greene received a controlling stock interest in the International company. 
In part due to the partial failure of these moves to merge firms within the industry, further moves to consolidate the industry did not occur. The industry thus continued to operate under a highly decentralized organizational structure.

Consolidation of textile firms into few large companies, although beginning during the first half of the twentieth century, did not happen as early, or often as in other industries in the U.S.A. Kennedy (1936) describes the mergers that did occur and the motivation for them. For example, he describes the type of control that was exemplified by the Lockwood Greene holding company's control through ownership of controlling stock interest. Another type was that of Consolidated Textile Corporation, which foresaw the complete acquisition of new mills. Mill companies increasingly realized the benefits of economies of scale through mergers, either horizontally or vertically.

\section{The Shift of Textiles to the South}

The center of gravity of U.S. cotton textile production shifted from the Northeast to the South between 1880 and 1930. Up until 1880, New England textile firms enjoyed national prominence. Value of product for the northern states declined from 1880 on relative to the south. In 1880 , the value of product for the North was $\$ 130,936,232$, while for the same year in the south the value of product 
was $\$ 13,315,840$. By 1930 the value of product for the northern states was $\$ 368,672,202$, while that of the south had risen to $\$ 873,623,564$, a dramatic increase relative to that of the north (See Table 1). Much of this change can be attributed to the shift of the textile industry to the South. The predominant advantage the south had was cheaper wages. In addition, factors such as lower taxes and cheaper fuel also helped in the process of luring away textile firms to the south.

Labor proved to be a more significant portion of the total manufacturing cost in New England than in the South. For example, in 1927, wages constituted 22.6 percent of value for fabrics produced in New England, but only 21.5 percent in the rest of the country. Further, the average annual wage paid to an operative in New England in 1927 was $\$ 944.00$, while elsewhere this was only $\$ 724.00$ (Burgy, 1932:145) One of the main reasons why wages were higher in the North was that the region was unionized, whereas in the South there was little, if any organized labor.

At the beginning of the emergence of the South, lack of skilled workers was a major inhibiting force. Wright (1981:605-629) ties growth of textile production in the South to the development of a skilled mill labor force between 1880 and 1930. The south began to infringe on the North gradually at first only in the production of coarse cloth types, which required little skill to produce. As 
TABLE 1

VALUE OF REGIONAL COTTON TEXTILE OUTPUT

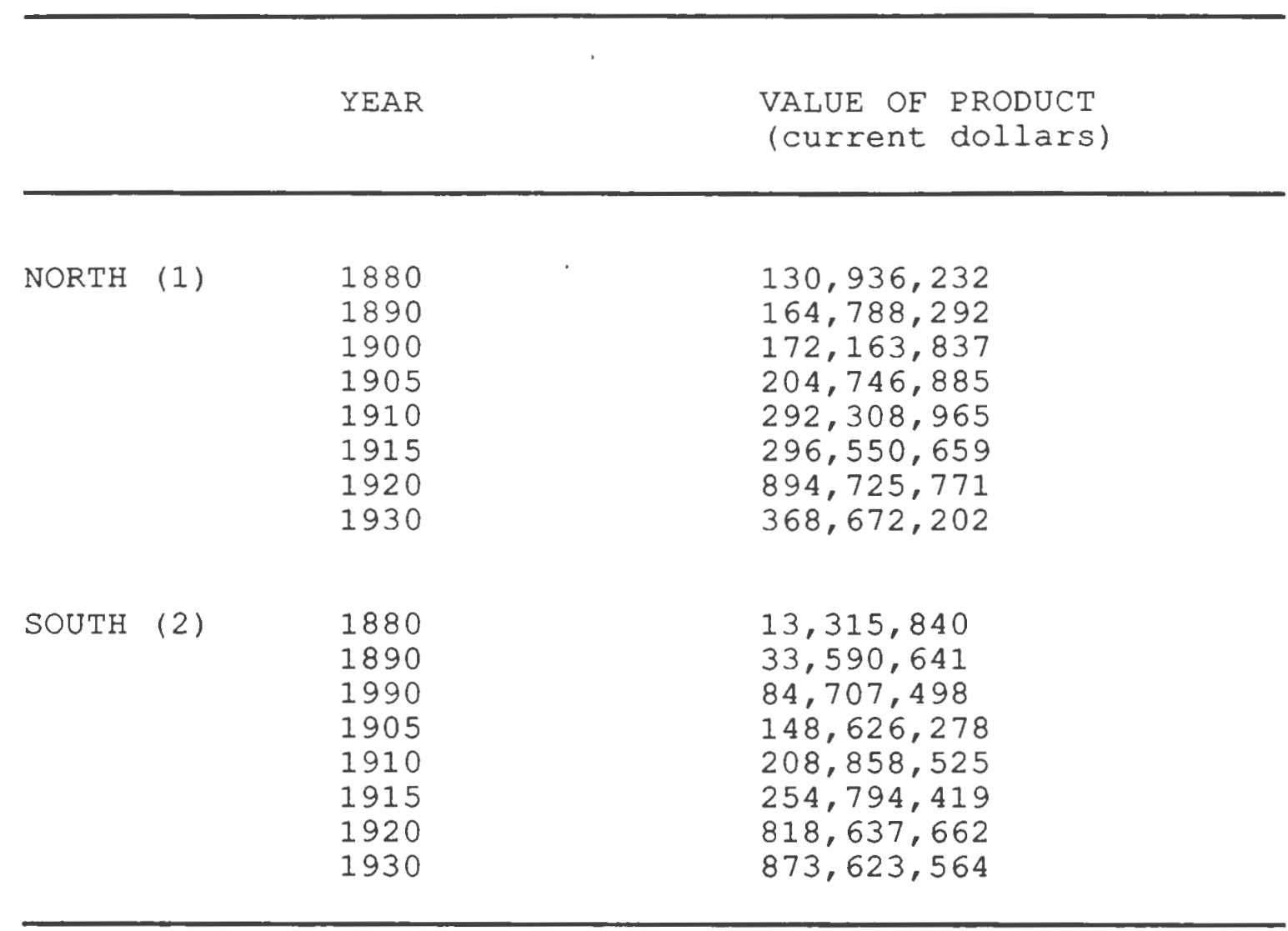

SOURCE: CENSUS OF MANUFACTURES, 1987

(1) NORTHERN STATES: MAINE, MASSACHUSETTS, NEW HAMPSHIRE, RHODE ISLAND

(2) SOUTHERN STATES: ALABAMA, GEORGIA, NORTH CAROLINA, SOUTH CAROLINA 
skill levels rose, the South started to infringe on segments of the textile industry in which cloth was of a more high grade quality. Southern workers initially achieved competency only in the simplest tasks because most of them came from rural areas and had little experience with the factory system. Wright further asserts that southern workers were less productive than Northern workers before 1930.

In addition to a shortage of skilled labor, Kane (1988:13) argues an insufficient supply of capital inhibited the building of mills in the South. Davis (1971) argues that barriers to capital mobility hindered the interregional flow of financial capital from the North to the capital scarce South. It was the second decade of the twentieth century before southern textiles clearly dominated the American market a domination that would almost certainly have been achieved a hundred years earlier had capital been more mobile.

Thus, after 1930 the textile industry in New England increasingly struggled to compete with the south. Added to this, a new competitor emerged on the scene beginning in the late $1960 \mathrm{~s}$ and $1970 \mathrm{~s}$.

\section{The Textile Industry Today}

The entrance of the developing nations into the arena of competition in manufacturing added mounting pressure to 
New England textile firms trying to find a lifeline in an increasingly hostile market.

In addition, demand began to stagnate. Since the $1970 \mathrm{~s}$ demand in the United States has grown at the rate of less than one percent annually. The two forces increased competition and squeezed profits. The response has been to attempt to raise labor productivity by investing in automated machinery. There has also been a rise in mergers as firms scramble to gain economies of scale and scope. The major response has been to move into specialty products. Firms in New England have sought to use existing machinery and technology combined in such a way as to yield them an advantage over the competition.

The growth of textile imports has had a profound effect on the textile industry as a whole. The trade deficit in textiles has risen dramatically in recent years. Net imports jumped to almost $\$ 1$ billion in 1983 and increased to $\$ 2.5$ billion in 1986 (See Table 2). This has been a growing trend from 1980 on (Kane, 1988:141).

Although the import share for textiles is not large relative to manufacturing as a whole, that share is rising. The strong dollar during the early 1980 s did not help this situation, but in the latter part of the 1980s the dollar weakened considerably. Still, textile imports have not been significantly affected by the fluctuating value of the dollar because most of the countries where the largest 
TABLE 2

TRADE DATA: TEXTILE MILL PRODUCTS (SIC 22)

(IN MILLIONS OF DOLLARS)

\begin{tabular}{llll}
\hline YEAR & $\begin{array}{l}\text { VALUE OF } \\
\text { IMPORTS }\end{array}$ & $\begin{array}{l}\text { VALUE OF } \\
\text { EXPORTS }\end{array}$ & NET IMPORTS \\
\hline & & & \\
1972 & 1,345 & 603 & 742 \\
1973 & 1,423 & 926 & 497 \\
1974 & 1,407 & 1,284 & 123 \\
1975 & 1,107 & 1,157 & -50 \\
1976 & 1,392 & 1,399 & -7 \\
1977 & 1,489 & 1,345 & 144 \\
1978 & 1,855 & 1,466 & -296 \\
1979 & 1,834 & 2,130 & -454 \\
1980 & 2,034 & 2,488 & 156 \\
1981 & 2,482 & 2,326 & 997 \\
1982 & 2,225 & 1,766 & 1,998 \\
1983 & 2,557 & 1,560 & 2,235 \\
1984 & 3,539 & 1,541 & 2,571 \\
1985 & 3,697 & 1,462 & \\
1986 & 4,322 & 1,751 & \\
\hline
\end{tabular}

SOURCE: DEPARTMENT OF COMMERCE, "TEXTILES" 1987 U.S. INDUSTRY OUTLOOK (JANUARY 1987) SEC. 42, 1-2 
proportion of textile imports come from have currencies pegged to the dollar. Increasingly, these countries are seeking out the U.S. market because those of Japan and the European Economic Community are more protected than the relatively open markets of the United States (Kane, $1988: 142)$.

Since 1973, the U.S. textile industry has been formally protected from foreign competition by the Multi-Fiber Agreement (MFA). This was renewed for a fourth time in 1986 for five years. The agreement defines a framework in which the fifty-one countries belonging to the General Agreement on Tariffs and Trade (GATT) can set textile import controls. Textile production has followed a recurrent pattern since the British textile mills lost their dominance in the nineteenth century. The center of textile manufacturing has continued to shift from the industrialized countries to the developing nations and regions, where wages are low. Britain in the nineteenth century lost out to New England, which in turn lost to the south, and today the south is losing to the developing nations of Asia.

The textile industry in New England continues to be battered by imports. Yet the New England firms are not blind to the need to change to regain market share. They are constrained in many ways, however. For example, to purchase new technologically advanced machinery is too expensive. The response appears to be the emergence of 
innovative new uses of old machinery to gain advantage over imports. Whether this response will be enough to prevent the industry from continuing to lose ground remains to be seen. 
CHAPTER 4

THE PRODUCTION PROCESS TODAY

\begin{abstract}
This chapter looks at textile finishing as distinct from textiles as a whole. Stout defines fabric finishing as:
\end{abstract}

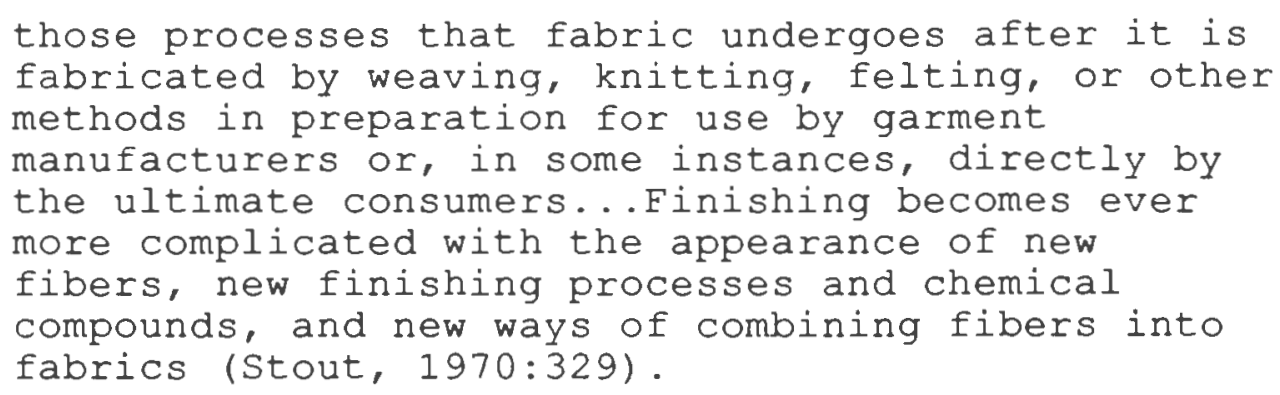

In 1970, when stout was writing, firms tended to include both the finishing process and the actual making of cloth. Stout goes on to note that despite this trend toward integration, in many large textile mills a large proportion of fabrics are still finished in mills other than the one where they are fabricated. Mills whose function is finishing are called converting mills, and persons who work there are known as convertors.

Fabrics as they come from the looms to the finishers are known as gray goods. This term has grown with increased usage to include any unfinished fabric and not just a fabric in need of bleaching. One would not except to find a gray good sold as the finished form, except perhaps in the case of industrial usage.

Stout provides a detailed list of five reasons for 
performing the task of finishing: to improve aesthetic qualities; to impart specific functional properties not inherent in fiber or fabric; to improve easy-care characteristics; to improve durability by improving certain service qualities; and to permit adaptation of present fabric constructions to changing market needs.

\section{Fabric Finishing Processes}

Fabric-finishing processes are categorized in different ways. These include: physical and chemical, wet and dry, for appearance and for function, and temporary and permanent. Stout (1970:331) divides finishes into three groups. These are:

general processes used for many fabrics to improve appearance, serviceability, or both; processes designed primarily to change appearance or surface texture, and for which any change in function or serviceability is largely incidental; and processes designed to give special functional or serviceability properties not inherent in the fiber or fabric, and in which any change of appearance is incidental.

Einishing processes used for many fabrics include cleaning, bleaching, drying, shrinkage control, heatsetting, inspection, repair, singeing, shearing, brushing, softening, sizing, weighting and fulling, tentering, dyeing, and mercerizing.

Cleaning encompasses all methods by which waxes, pectins, soil, lubricants, warp sizing, and other alien substances still left on the fibers, are removed in 
preparation for other finishing processes. The process also includes any final cleaning of the fabric before it goes to the consumer. The cleaning process includes scouring and washing with soap and water, dry cleaning, and enzyme treatment for removal of sizing, starches etc.

Bleaching is a chemical process that removes the color from the cloth by the use of chlorine or sodium compounds, or by the use of hydrogen peroxide. The bleaching process is used on natural fibers to even color. Fabrics are then dyed or left white depending on color chosen for the final product. Cotton is also bleached due to the existence of occasional black flecks. Bleaching also performs the function of destroying any microorganisms that are present in the fabric, and it increases the fabrics absorbency. Drying both removes moisture from the cloth and eradicates folds, creases and wrinkles. The latter can be achieved by pressing, tension, or blowing. There are several different methods used for drying. Stout offers the example of the oldest method of drying which involves the use of calendar rolls between which opened-out fabrics are passed.

Shrinkage control is obtained by the use of one of three methods. The choice of the method will depend on the type of fabric being finished and the use for which the fabric is planned. The three methods are heat-setting, compressive shrinkage, and stabilization by treatment with 
thermosetting resins. Heat-setting is the process whereby a rearrangement and fixation of the internal molecular structure of nylon occurs. Internal stresses in the material are relieved and the fibers tend to assume a permanent structural arrangement in which they are held during the setting treatment. Compressive shrinkage is the process whereby the overstretching distortion of fabric during weaving or other processing is removed by dampening the cloth and drying it in a relaxed condition so as to remove tensions or distortions. Thermosetting resins are applied in a liquid form. The fabric is pinned or clipped to the dimensions needed on tenter frames, and then the resin is heat cured. Success of this treatment depends on the susceptibility of the fibers to the treatment, the amount of resin used in the process, and the subsequent processing and care.

Inspection is the process by which the fabric is examined to locate defects, which are then marked for repair. The process is carried out with the fabric opened up and placed under a light so that any defects can be clearly seen. Any repairable imperfections in the fabric are also dealt with at this stage.

Singeing is the process by which fiber, projecting yarn ends, and other fuzz is burnt off to leave the fabric with a smooth, even surface. The mechanics of this operation involve the passing of the fabric over gas flames or hot 
plates at a speed fast enough so that the fabric itself is not burned but any protruding material is removed by burning. The fabric is then passed over a wet surface to insure the extinguishing of any smoldering fibers.

Shearing is the process of cutting pile to a uniform height, or in certain cases, eradicating all fuzz from the fabric. Shearing may occur several times for maximum evenness.

Weighting, softening, sizing and fulling, are processes for changing the feel of fabrics, to replace waxes, gums, or oils lost in finishing, and to increase flexibility and drape of the fabric. Weighting is the process by which silk is treated with metallic salts to give weight and body to the fabric. Lead, zinc, and tin have been used in this process, although today lead is no longer used because of the health hazards associated with its use.

Softening is the process by which one or more products is added to the fabric to make it softer. Softening agents used include dextrin, glycerin, sulfonated oils, waxes, and soaps .

Sizing is a yarn process in preparation for weaving. Fulling agents, when applied, have the same effect on wool as sizing materials on other fabrics. This effect is used as a finishing process on wool products. Some of these products are removed from the cloth as a result of wear or washing, while others are durable. 
Tentering, crabbing, and heat-setting are described as:

the final processes by which warp and filling of woven fabrics are set at right angles to each other and pulled out to the dimensions at which they are to be dried as finished products. Crabbing is the term applied to wet-tentering of wool; heat-setting is used for most of the thermoplastic fibers. Pins or clips grasp the selvages and hold the fabric in place as it travels through the machine, releasing it at the end where it is folded or rolled for packaging (Stout, 1970:335).

The processes described above are the general processes used in finishing of most fabrics. Numerous other, more specialized finishing processes are also used. 5

\section{Textile Finishing SIC Codes}

The umbrella Standard Industry Classification (SIC) code for textiles is 22 , and within this there are ten SIC codes under the heading of finishing. These are Broadwoven Fabric Mills, (SIC 2231); the knitting industries in SIC 225 involved in finishing (SICs 2251, 2252, 2257, 2258), Cotton Finishing Plants, (SIC 2261); Manmade Finishing Plants, (SIC 2262); N.E.C. (Not Elsewhere Classified) finishing plants, (2269): Yarn Spinning Mills, (SIC 2281); and Coated Fabrics, Not Rubberized, (SIC 2295).

SIC code 2231, Broadwoven Fabric Mills, Wool, is made up of establishments primarily engaged in weaving fabrics more than 12 inches in width, wholly or chiefly by weight of

5 For a thorough discussion of more specialized processes, see Stout, 1970:337-352. 
wool, mohair, or similar animal fibers; dyeing and finishing all woven wool fabrics or dyeing wool, tops or yarn; and those shrinking and sponging wool goods for the trade. The SIC code group 225 includes four finishing codes. SIC 2251 is made up of establishments primarily engaged in knitting, dyeing, or finishing women's and misses' full-length and knee-length hosiery, both seamless, full-fashion, and pantyhose. SIC 2252 is comprised of firms engaged in knitting, dyeing, or finishing hosiery, not elsewhere classified. SIC 2257, Weft Knit Fabric Mills is comprised of firms engaged in the making of knitting weft knit fabrics or in dyeing, or finishing weft knit fabrics. SIC 2258, Lace and Warp Knit Fabric Mills, is made of firms engaged in producing knitting, dyeing, or finishing warp knit fabrics, or in manufacturing, dyeing, or finishing lace goods. SIC 2281, Yarn Spinning Mills, is made up of establishments primarily engaged in spinning yarn wholly or chiefly by weight of cotton, manmade fibers, silk, wool, mohair, or similar animal fibers. SIC 2295, Coated Fabrics, Not Rubberized, is made up of establishments primarily engaged in manufacturing coated, impregnated, or laminated textiles, and in the special finishing of textiles, such as varnishing and waxing. SIC 2261, the cotton Finishing Plant industry is made up of establishments engaged in finishing purchased cotton broadwoven fabrics, or finishing such fabrics on a commission basis. This SIC code also includes firms engaged 
in the shrinking and sponging of cotton fabrics and chemical finishing for water repellency, fire resistance, and mildew proofing. Industries coded under SIC code 2262, Manmade Finishing Plants, are those engaged in finishing purchased manmade fiber and silk broadwoven fabrics, or finishing such fabrics on a commission basis. Industry classification 2269, N.E.C. Finishing Plants, is made up of firms engaged in dyeing and finishing textiles, not elsewhere classified. This includes bleaching, dyeing, printing, and finishing of raw stock, yarn, braided goods, and narrow fabrics lexcept wool and knit fabrics) (Department of Commerce, Bureau of the Census, 1987).6

\section{Total Employment Within Textile Finishing}

Total employment in textile finishing has declined since 1972. Total employment for the sector, as defined by the ten SIC codes, declined from 1972 through 1982. After 1982 the industry rallied to regain lost ground, but still did not begin to approach anywhere near the level of its 1972 employment. From 1972 to 1977 employment fell 16.7 percent, from 389.8 thousand to 333.9 thousand. From 1977

6 In terms of the way in which the Census of Manufactures has reported the statistics used in this chapter, the statistics, including figures for employment, payroll, etc are reported for each establishment as a whole. Aggregates of such data for an industry reflect not only the primary activities of the establishments, but also their activities in the manufacture of secondary products as well as their miscellaneous activities, including each firm's activities as contract work on materials owned by others and such work as repairs. 
to 1982 employment decreased by another 22.3 percent, from 333.9 thousand workers to 273.1 thousand. From 1982 to 1987 employment in the industry rose from 273.1 thousand to 290.7 thousand, an increase of 6.1 percent (See Table 3).

Further, the textile industry lost out in terms of the percentage employed within total manufacturing. This share fell from 2.05 percent of total manufacturing in 1972, to 1.54 percent of total manufacturing in 1987 (See Table 3). SIC code 2231, broadwoven fabric mills, wool, has seen a significant decline in numbers employed. Employment fell from 19.4 thousand in 1972 to 13.1 thousand in 1982. 1987 saw a slight recovery from the 1982 low point to 13.8 thousand.

SIC code 2251 saw a long-term fall in numbers employed from a 1972 figure of 49.5 thousand to 29.3 thousand in 1987.

In SIC code 2252 an increase occurred in workers employed. The figure rose from 32.6 thousand in 1972 to a high of 36.5 thousand in 1987.

SIC code 2257 saw a sharp decline in numbers employed from 1972 to 1987. The figure of employed persons fell from 68.1 thousand in 1972 to 34.9 thousand in 1987.

SIC code 2258 saw an initial increase in employment from 1972 to 1977, but thereafter a decline set in. The number of workers rose from 24.9 thousand in 1972 to 25.9 thousand in 1977. The fall occurred from 1977 through 1987 
TABLE 3

TOTAL TEXTILE FINISHING EMPLOYMENT

AS A PERCENTAGE OF TOTAL MANUFACTURING EMPLOYMENT

IN THE UNITED STATES, 1972-1987

\begin{tabular}{llll}
\hline YEAR & $\begin{array}{l}\text { TOTAL TEXTILE } \\
\text { FINISHING }\end{array}$ & $\begin{array}{l}\text { TOTAL } \\
\text { MANUFACTURING }\end{array}$ & $\begin{array}{l}\text { O } \\
\text { IN MA TEXTILES }\end{array}$ \\
\hline & & & \\
1972 & 389,800 & 19,000000 & 2.05 \\
1977 & 333,900 & 19,600000 & 1.71 \\
1982 & 273,100 & 19,100000 & 1.43 \\
1987 & 290,700 & 18,900000 & 1.54 \\
\hline
\end{tabular}

SOURCE: UNITED STATES CENSUS OF MANUFACTURES, 1987

STATISTICAL ABSTRACT OF THE UNITED STATES, 1990 
when the numbers employed fell from 25.9 thousand to 20.5 thousand.

SIC code 2261, cotton finishing plants, declined consistently from 1972 through 1982, but then appeared to recover slightly in 1987. Total employment in SIC code 2261 in 1972 was 25.7 thousand, but by 1982 this figure had fallen to 11.6 thousand, with a recovery to 16.6 thousand in 1987.

SIC code 2262, manmade finishing plants, saw an increase from 1972 to 1977. However, after the 1977 increase the SIC code experienced a steady decrease. In 1972 SIC code 2262 employed 35.2 thousand workers. By 1977 this figure had risen to 37.2 thousand. The employment figure declined from this 1977 level to 27.9 thousand in 1987.

In SIC code 2269, N.E.C. finishing plants, employment fell in 2269 from 1972 through 1982, with a small decrease between 1982 and 1987. In 1972 the total employment in SIC Code 2269 was 18.5 thousand. This fell to 12.0 thousand by 1982. By 1987 employment had decreased employment to 11.8 thousand.

In SIC code 2281, total employment fell from 97.9 thousand in 1972 to 76 thousand in 1982. It recovered in 1987 to 89.1 thousand persons employed. SIC code 2295 has steadily lost jobs since 1972 when the numbers employed were 18 thousand. By 1987 this number 
had fallen to only 10.3 thousand workers (See Table 4).

One might speculate that with the recession of 1991,

and the manufacturing sector being hard hit, figures for the next five year period may well show an accelerated downturn. 
TABLE 4

TEXTILE FINISHING

TOTAL EMPLOYMENT BY SIC CODE

FOR 1972-1987 (THOUSANDS)

\begin{tabular}{lllll}
\hline SIC & & & & \\
& 1972 & 1977 & 1982 & 1987 \\
& & & & \\
2231 & 19.4 & 14.6 & 13.1 & 13.8 \\
2251 & 49.5 & 26.6 & 30.2 & 29.3 \\
2252 & 32.6 & 32.2 & 32.6 & 36.5 \\
2257 & 68.1 & 51.8 & 31.1 & 34.9 \\
2258 & 24.9 & 25.9 & 21.1 & 20.5 \\
2261 & 25.7 & 20.8 & 11.6 & 16.6 \\
2262 & 35.2 & 37.2 & 34.4 & 27.9 \\
2269 & 18.5 & 14.1 & 12.0 & 11.8 \\
2281 & 97.9 & 97.1 & 76.0 & 89.1 \\
2295 & 18.0 & 13.6 & 11.0 & 10.3 \\
& & & & \\
\hline TOTAL & 389.8 & 333.9 & 273.1 & 290.7 \\
\hline
\end{tabular}

SOURCE: UNITED STATES CENSUS OF MANUFACTURES, 1987 


\section{CHAPTER 5}

\section{INDUSTRIAL ORGANIZATION}

This chapter profiles industrial organization in textile finishing.

\section{Overview}

The textile industry as a whole is suffering from import pressures, rising raw materials prices, and stagnating demand, and this has significant implications for textile finishing. When unfinished textile goods work their way down the line to the finishing stage, they too are confronted with reduced volume, higher prices passed on as a result of rising raw materials prices, and less work due to a rising share of the domestic market being held by cheaper foreign imports (See Table 5).

\section{Employment Trends in the Textile Industry}

The national figures for total employment in textile finishing presented in Chapter 4 (Table 4) highlight a decline in employment in the industry up to 1982 and then a recovery between 1982 and 1987. By 1989 the textile industry as a whole had recovered somewhat, from the 1988 fall that had adversely affected earnings. ${ }^{7}$ Profitability

7 Standard and Poors (1990) discusses profitability in the entire textile industry (SIC 22). Data on profitability in textile finishing alone are not available, so data may not apply exactly. 
TABLE 5

UNITED STATES IMPORTS AND EXPORTS

OF TEXTILES (IN MILLIONS OF POUNDS)

\begin{tabular}{lll}
\hline & & \\
YEAR & IMPORTS TOTAL & \\
& & \\
& & \\
1988 & & $1,043.0$ \\
1987 & $4,078.9$ & 910.9 \\
1986 & $4,293.7$ & 785.9 \\
1985 & $3,875.8$ & 681.5 \\
1984 & $3,343.8$ & 703.9 \\
1983 & $2,765.8$ & 694.0 \\
1982 & $2,165.7$ & $1,014.0$ \\
1981 & $1,692.6$ & $1,299.0$ \\
1980 & $1,690.4$ & $1,075.0$ \\
1979 & $1,433.8$ & \\
& $1,345.2$ & \\
\hline
\end{tabular}

SOURCE: AMERCIAN TEXTILE MANUFCTURERS INSTITUTE, 1989 
has risen since the beginning of the 1980s, when as a response to stiff competition from overseas, and a deep recession, the industry began to restructure. The restructuring included closings of numerous plants and laying off large numbers of workers. Capital expenditures on advanced technology, automated manufacturing systems and automated machinery have increased the domestic industry's competitive position. Reduction in the value of the dollar has also helped make U.S. products more competitive on the world market, helping to offset some of the cost advantages of foreign textiles.

The weakening dollar, however, does not tell the whole story. By the end of 1989, the Commerce Department's index of new orders was down $10.5 \%$ from the corresponding period of 1988; and as of the end of February 1990, the new order rate stood $9.9 \%$ below the year-earlier level. The rate of unfilled orders was also not encouraging. At year-end 1989, unfilled orders were just $0.4 \%$ ahead of the same period of 1988. As new orders have softened, the unfilled order rate has headed south, and as of February 1990 it was $6.1 \%$ lower than the previous year. Textile profits are expected to be hurt by the slower volume, raw materials prices, and renewed competitive pressure from imports ( Standard and Poors, $1990: 517-780)$. 


\section{Restructuring}

The U.S. textile industry, as with most manufacturing industries, was hard-hit by the recession of the early $1980 \mathrm{~s}$ and the one beginning in 1990. With restructuring, there has been a trend toward consolidation. Standard and poors notes that of the fifteen largest publicly-traded textile companies ten years ago, only three remain, all a result of consolidation activity (Standard and Poors, 1990:517-780). Several factors underlie this restructuring and consolidation process. Competition from foreign imports is a key factor. Standard and Poors (1990:517-780) observes that while:

disposable personal income has increased an average of $9.7 \%$ annually since 1980 , sales of U.S. textile mill products increased only $1.9 \%$ annually during that period. Failing to reap the implied benefits of growth in consumer spending, the industry turned to acquisitions (in textiles) to achieve that growth.

The trend toward consolidation has also been spurred by a desire on the part of certain companies to become market leaders in core businesses. This allows firms to increase their shares of existing markets, and to acquire shares of new markets. Through consolidation firms also achieve economies of scale and scope.

\section{Imports}

The import threat has been one of the major forces that has led to the rising number of acquisitions. Standard and 
Poors observes that between 1980 and 1989, imports of yarn, fabric, and miscellaneous textiles (excluding apparel) grew to $6,077.5$ million square yards, from 2,000.2 million square yards. In 1989, total textile imports, as measured in millions of square yards, grew $12.7 \%$, with textile imports up 11.2\%, and apparel up 14.2\%. Imports have consisted primarily of short-run fabrics, labor intensive fabrics, and apparel products. This implies the thesis about increases in short runs is correct.

Domestic textile producers are placing less emphasis on segments of the industry that compete directly with imports and have looked to areas of the industry in which they can produce at a relatively low cost and where import penetration is less likely.

Domestic firms have also moved to enter "nicheoriented" high-margin areas. Standard and Poors gives the example of Guildford Mills pioneering specializing fabric finishing techniques that were unavailable elsewhere.

By eliminating unprofitable plants and through massive layoffs the industry has managed to increase productivity. Older machines have been replaced with new automated machinery, and capacity has grown. According to Standard and Poors (1990:517-780), despite a 15\% decline in employment, production in the industry increased by $24 \%$ between 1980 and 1989 .

Most new investment by the industry is expected to be 
to enhance productivity, rather than increase capacity.

Standard and Poors observes that textile industry earnings as a percentage of sales have varied widely. This is very much a reflection of the tendency for variation in manufacturing as a whole, although textile earnings are generally seen to cover a wider range.

Despite improved productivity and profitability, profit margins within the industry remain low. In 1988 and 1989, for example, net profits for all manufacturing companies were $5.9 \%$ and $5.0 \%$, but in textiles were $3.1 \%$ and $2.5 \%$, respectively (Standard and Poors:1990).

In addition to modernizing operations and reducing the size of the workforce while increasing productivity, textile firms have attempted a series of profit-enhancing activities. They have also sought to achieve greater asset management and to increase inventory turnover. However, such factors as high real interest rates worked against the industry in the 1980 s.

\section{Textile Wages}

Wages in the textile industry are lower than the wages for all manufacturing. However, since 1985 the gap has narrowed somewhat. In 1980, average textile wages per week were 70.27 percent of all manufacturing wages. In 1985 this percentage fell to 68.84 percent, but by 1989 the percent had recovered somewhat to 73.35 percent. (See Table 6) 
TABLE 6

TEXTILE INDUSTRY WAGES AND EMPLOYMENT

\begin{tabular}{|c|c|c|c|c|c|}
\hline & $\$$ PER HOU & & AVG WK EA & RNINGS $\$$ & TOTAL EMPLY \\
\hline YEAR & $\begin{array}{l}\text { TEXTILE } \\
\text { MILL MFG }\end{array}$ & $\begin{array}{l}\text { ALL } \\
\text { MFG }\end{array}$ & $\begin{array}{l}\text { TEXTILE } \\
\text { MILL MFG }\end{array}$ & $\begin{array}{l}\text { ALL } \\
\text { MFG }\end{array}$ & $\begin{array}{l}\text { TEXTILE MILU } \\
\text { EMPLY } 1000 \mathrm{~s}\end{array}$ \\
\hline $\begin{array}{l}1989 \\
1988 \\
1987 \\
1986 \\
1985 \\
1984 \\
1983 \\
1982 \\
1981 \\
1980\end{array}$ & $\begin{array}{l}7.68 \\
7.37 \\
7.17 \\
6.93 \\
6.70 \\
6.46 \\
6.18 \\
5.83 \\
5.52 \\
5.07\end{array}$ & $\begin{array}{l}10.47 \\
10.17 \\
9.91 \\
9.73 \\
9.54 \\
9.19 \\
8.84 \\
8.50 \\
7.98 \\
7.27\end{array}$ & $\begin{array}{l}314.88 \\
302.91 \\
299.71 \\
284.82 \\
265.99 \\
257.75 \\
249.67 \\
218.63 \\
219.14 \\
202.80\end{array}$ & $\begin{array}{l}429.27 \\
417.99 \\
406.31 \\
396.01 \\
386.37 \\
373.22 \\
354.48 \\
330.65 \\
317.60 \\
288.62\end{array}$ & $\begin{array}{l}726.1 \\
725.8 \\
724.5 \\
703.2 \\
702.3 \\
752.8 \\
743.8 \\
748.9 \\
839.3 \\
863.8\end{array}$ \\
\hline
\end{tabular}

SOURCE: BUREAU OF LABOR STATISTICS, 1990 
Union membership has declined in Clothing and Textile Workers union from 440,000 members in 1971 to 228,000 members in 1985. This decline is in line with the national reduction in total union membership in all trades.

\section{Number of Establishments}

Table 7 breaks down number of establishments by state, and SIC code. Massachusetts consistently has the most establishments although, the state also has the largest population in New England. Even though firms employ over 20 persons than employ below twenty persons, the average size of finishing firms is small.

\section{State of the Industry}

The discussion above provides a picture of an industry struggling to survive in the new global economy. The industry has restructured since imports began to have a strong impact in the beginning of the 1980s. However, despite discarding inefficient mills, laying off workers, and adopting automated machinery, the industry continues to struggle to survive.

The industry's strategy has been to invest in increased productivity, rather than increased capacity. This choice makes sense in the current economic climate, as demand is stagnant. Despite reductions in the workforce, the industry continues to be less profitable than manufacturing 
TABLE 7

TOTAL NUMBER OF ESTABLISHMENTS IN NEW ENGLAND TEXTILE FINISHING SIC CODES WITH NUMBERS SHOWN FOR THOSE ESTABLISHMENTS EMPLOYING TWENTY OR MORE PERSONS

\begin{tabular}{|c|c|c|c|c|c|c|c|c|c|c|}
\hline & & & & SIC & CODE & & & & & \\
\hline & 2231 & 2251 & 2252 & 2257 & 2258 & 2261 & 2262 & 2269 & 2281 & 2295 \\
\hline \multicolumn{11}{|l|}{ CONNECTICUT } \\
\hline TOTAL ESTABS & 4 & 0 & 0 & 0 & 6 & 4 & 7 & 0 & 0 & 7 \\
\hline $\begin{array}{l}\text { TOTAL ESTABS } \\
\text { WITH } 20+\end{array}$ & 2 & 0 & 0 & 0 & 4 & 3 & 5 & 0 & 0 & 5 \\
\hline \multicolumn{11}{|l|}{ MAINE } \\
\hline TOTAL ESTABS & 9 & 0 & 0 & 0 & 0 & 0 & 0 & 0 & 11 & 0 \\
\hline $\begin{array}{l}\text { TOTAL ESTABS } \\
\text { WITH } 20+\end{array}$ & 6 & 0 & 0 & 0 & 0 & 0 & 0 & 0 & 9 & 0 \\
\hline \multicolumn{11}{|l|}{ MASSACHUSETTS } \\
\hline TOTAL ESTABS & 16 & 0 & 0 & 6 & 0 & 12 & 16 & 7 & 11 & 18 \\
\hline $\begin{array}{l}\text { TOTAL ESTABS } \\
\text { WITH } 20+\end{array}$ & 9 & 0 & 0 & 5 & 0 & 8 & 14 & 3 & 7 & 10 \\
\hline \multicolumn{11}{|l|}{ NEW HAMP SHIRE } \\
\hline TOTAL ESTABS & 6 & 0 & 0 & 0 & 3 & 1 & 0 & 0 & 0 & 0 \\
\hline $\begin{array}{l}\text { TOTAL ESTABS } \\
\text { WITH } 20+\end{array}$ & 4 & 0 & 0 & 0 & 3 & 1 & 0 & 0 & 0 & 0 \\
\hline \multicolumn{11}{|l|}{ RHODE ISLAND } \\
\hline TOTAL ESTABS & 10 & 0 & 0 & 8 & 17 & 9 & 5 & 5 & 0 & 3 \\
\hline $\begin{array}{l}\text { TOTAL ESTABS } \\
\text { WITH } 20+\end{array}$ & 8 & 0 & 0 & 3 & 12 & 5 & 4 & 2 & 0 & 2 \\
\hline \multicolumn{11}{|l|}{ VERMONT } \\
\hline TOTAL ESTABS & 0 & 0 & 0 & 0 & 0 & 0 & 0 & 0 & 4 & 0 \\
\hline $\begin{array}{l}\text { TOTAL ESTABS } \\
\text { WITH } 20+\end{array}$ & 0 & 0 & 0 & 0 & 0 & 0 & 0 & 0 & 3 & 0 \\
\hline
\end{tabular}

SOURCE: U.S. CENSUS OF MANUFACTURES, 1987 
as a whole.

U.S. firms have chosen to retreat to segments of the industry where they can compete with imports. This has led to high-tech segments of the industry, a strategy that works because the developing nations do not have similar technological abilities. The problem with this approach is that eventually the developing nations may develop capabilities in technology and be able to compete in these sectors. 


\section{CHAPTER 6}

\section{IS FIEXIBILITY INCREASING IN THE TEXTILE FINISHING INDUSTRY IN NEW ENGLAND?}

This chapter addresses the issue of whether there is evidence that the textile finishing industry in New England is becoming flexibly specialized. An important point to note is that the flexibility theory as presented in Chapter 2, The Flexibility Debate, is still being debated by academics and no consensus has yet been reached.

Criticism of flexible specialization theory as advocated by Piore and Sabel (1984) centers around reliance on arbitrarily selected case studies of local areas that are then specialized without justification. Amin (1989) argues that unique circumstances in the chosen study areas were the reason flexible specialization thrived, rather than just flexible specialization itself being the cause of the areas' success. ${ }^{8}$

As the flexibility debate has developed, some studies have found some, although not all, of the attributes of the classic definition of flexible specialization are to be present; enough indeed to support some of the assertions made by the theory, for example, the assertion that Nike is

${ }^{8}$ See Piore, Sabel (1984) for a discussion of industrial districts in the Third Italy, particularly the textile industry in Prato. Also see Amin (1989) for a comprehensive criticism of flexible specialization in industrial districts and a critique of the theory's wider applicability.) 
flexibly integrated (Donaghu and Barff, 1990).

\section{Flexibility and the Textile Finishing in New England}

This chapter argues that the textile finishing industry in New England shows signs of some of the traits of flexibility. However, the industry cannot be called flexible in the classic sense of the definition for several reasons.

\section{Organizational structure}

The organizational structure of textile finishing firms in New England is much the same as it was fifty years ago. It is characterized by separation of management and shop floor workers, little shop floor involvement in company policy, performance of only one task per worker, uncomfortable working conditions for those on the shop floor, and little unionization. The outward appearance of the firms is that of textile companies still struggling to enter the twentieth century. The spatial location of the textile finishing firms in New England is largely a result of the original location of the firms where the industry grew up from the late 1700 s on. The firms that remain today are largely those that survived the move of the textile industry to the South, and have managed to withstand import competition pressures. Thus the firms location cannot be attributed to flexible specialization. 
Employee Policies

Many employee policies are still typical of those one would expect to find in a manufacturing firm in the 1940 s or 1950s. The workers are given one job to do and only know one job, they are unskilled or at best semi-skilled, their hours are rigid aside from overtime, and their work for the most part requires little thought.

\section{Machinery}

Much of the machinery that textile finishing firms use is not technologically advanced. Rather than purchasing new technologically advanced machinery, some of the firms interviewed chose to employ workers to maintain the machines.

\section{The Blurring of the Lines Between Mass Production and} Flexible Specialization

One must not overlook Gertler's (1988) argument that we are not experiencing a dramatic break from the past, but that batch production existed under fordism. This point is very relevant to the New England textile finishing industry, which does not fit neatly into the definition of mass production. Some of the traits associated with flexible specialization have been have been present for many years. For example, many small firms with low and moderate numbers of workers exist in the industry. 
Walker (1990) argues extensively that the debate is not about a dichotomy. The choice is not simply one of whether an industry uses flexible specialization or mass production. This simplifies a complex reality in which overlaps are plentiful. Walker (1990: 62-63) asserts that the source of confusion is:

the misplaced emphasis on scale of output (length of runs) instead of production methods (type of machinery). One may get very long runs out of generalized machinery or short runs out of dedicated machinery, with corresponding effects on overall efficiency of labour and machine use, but the principles of mechanical improvement in each case are different.

Walker's argument with regard to dedicated machinery raises an important point, but he fails to take the argument far enough to emphasize the importance of looking more closely at dedicated machinery. Flexibility in much of New England's textile finishing industry rests on the firms' ability to use old dedicated machinery in flexible ways. Flexibility here is achieved by the operatives ability to use the machine in subtly different ways to create a different fabric or finish. For example, at Company $y$, this type of flexibility was demonstrated by the machine operatives' ability to use the same machine to achieve widely varying dyes on fabrics.

Currently there is no well developed literature or theory to explain the form of flexibility which seems to be occurring in the New England textile industry. 


\section{Textile Finishing in New England}

The textile finishing industry in New England has recognized the inevitability of large sections of the textile business being taken over by cheap foreign imports. In many cases (usually in the cases of those who have survived) the industry's way of dealing with this threat has been to retreat into niche-oriented production areas, where superior use of finishing processes has allowed domestic firms a winning advantage over imports. It is important to note that the niche-strategy is a defensive strategy rather than an offensive one.

This realization however does not seem to have stemmed the decline in employment in the industry. There has been a deliberate policy to increase productivity. The emphasis in the industry has shifted from increasing capacity to increasing efficiency.

\section{Characterization of the New England Textile Finishing Industry}

$$
\text { The New England textile finishing industry is }
$$

characterized by:

* Declining total employment

* Rising import competition

* Large numbers of small or medium sized establishments

* Lower wages relative to manufacturing as a whole

* A move to seek niches where firms can insulate themselves from foreign competition 
This characterization will be used to argue that the industry cannot be called flexibly specialized in the classic sense of the definition, but that, as discussed above it rather has "touches" of flexibility.

Total Employment in Textile Finishing

Total employment in the textile industry has been declining in New England since the South became a significant competitor in the market after 1880. The industry in New England is now also facing intense competition from imports. In Rhode Island alone between 1949 and 1978 seventy three textile mills closed, causing a loss of some 20,122 jobs (Greenhouse compact, 1983).

In the textile finishing SIC codes 2231, 2251, 2252, $2257,2258,2261,2262,2269,2281$, and 2295, total employment in the United States fell from 389,800 in 1972 to 290,700 in 1987 , a 34.1 percent decline. In contrast to this picture of a declining industry, the industrial district in Prato, Italy where Piore and Sabel (1984) first found flexible specialization has had steadily rising numbers of jobs. Amin (1989:20) points to a 28.5 percent growth in employment in firms with less than 99 employees between 1971 and $1981 .{ }^{9}$

9 This increase was for all manufacturing firms in the Third Italy, not just textiles. 
Rising Import Competition

Table 8 contains import and export figures in the textile finishing SIC codes for the years 1972 through 1985. For the SIC codes in which comparisons are possible (ie where zero is not reported for both imports and exports or one or the other, SIC 2231, 2251, 2257, 2281,2295) the table gives figures on the relative gain or loss made by imports over exports.

In SIC 2231, Weaving and Finishing Mills-Wool, imports increased 83.8 percent, from $\$ 32$ million to $\$ 197$ million. During the same period, exports increased 81 percent from $\$ 1.5$ million to $\$ 7.9$ million.

In SIC code 2251, Women's Hosiery, Except Socks, imports increased 84.9 percent, from $\$ 10.1$ million in 1972 to $\$ 66.8$ million. Over the same time period exports increased 86 percent from $\$ 1.5$ million to $\$ 10.7$ million.

In SIC 2257, Circular Knit Fabric Mills, imports decreased by 316.9 percent from $\$ 123$ million in 1972 to $\$ 29.5$ million in 1985 . Over the same time period exports increased 55.2 percent, from $\$ 21.4$ million to $\$ 47.8$ million.

In SIC 2281, Yarn Mills, Except Wool, imports increased by 79.1 percent from $\$ 29.1$ million in 1972 to $\$ 139.4$ million in 1985. Over the same time period, exports increased by 71.5 percent from $\$ 22.6$ million to $\$ 79.4$ miliion.

In SIC 2295 imports increased 49.8 percent from $\$ 30.1$ million in 1972 to $\$ 59.9$ million in 1985 . Over the same 
TAELE 2

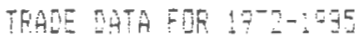

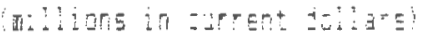

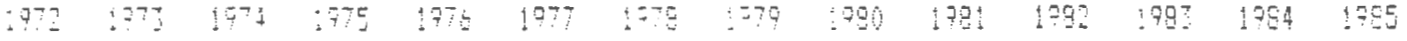

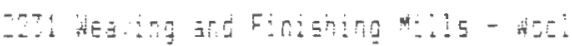

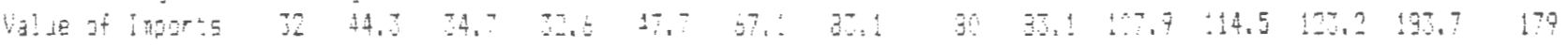

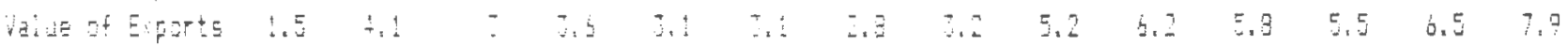

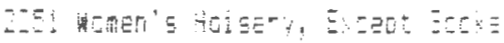

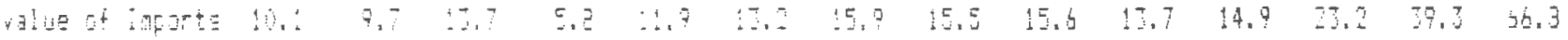

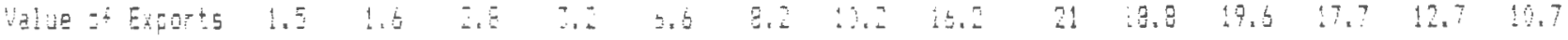

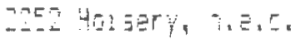

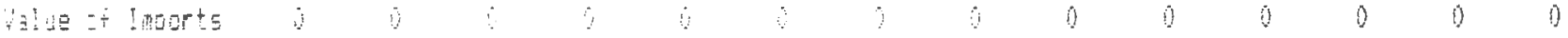

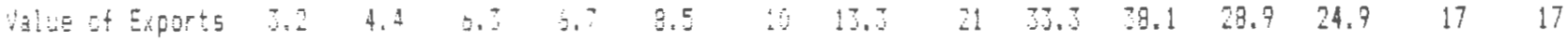

2257 circular hit. 5atrie Mil!s

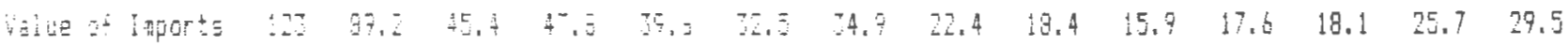

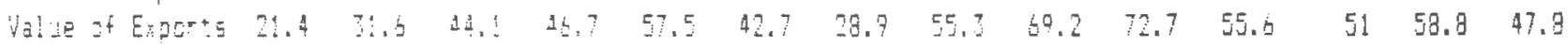

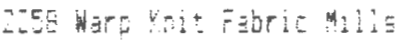

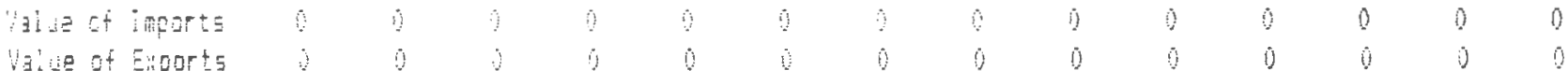

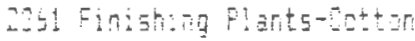

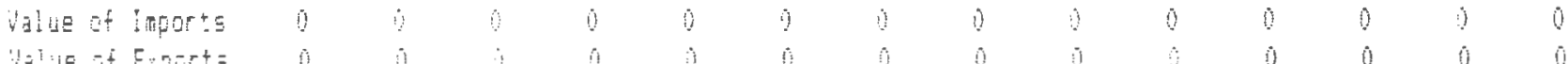

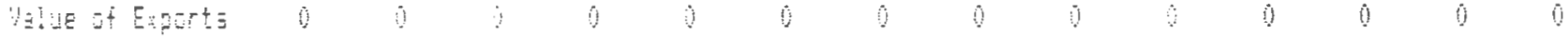

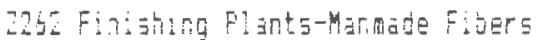

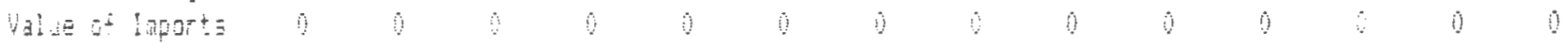

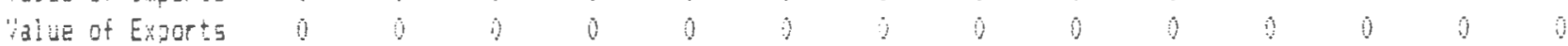

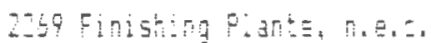

'Alive of lmorts i o

Walue of Exports :

223: Yarn Mills, Except dool

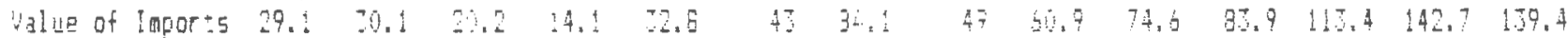

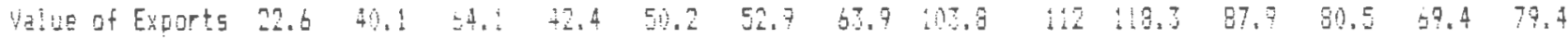

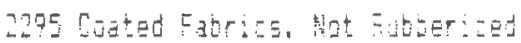

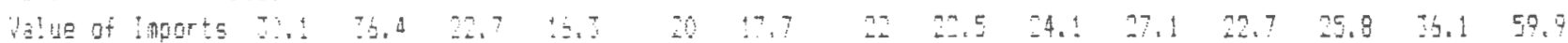

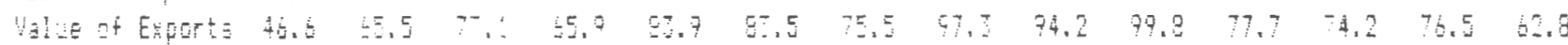

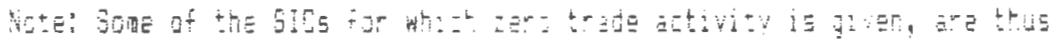

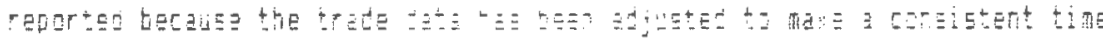

Egr:

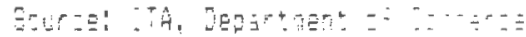


time period exports increased 25.8 percent from $\$ 46.6$ million to $\$ 62.8 \mathrm{million}$.

The percent increases for exports are somewhat misleading when compared with percent increases for imports as the import figures are much larger than the export figures.

Significant Numbers of Small or Medium Sized Establishments Table 9 contains the numbers of establishments in the textile finishing SIC codes, and the number of establishments with employees of 1-19, 20-99, and over 100 . If one defines "small and medium sized firms" as those employing under 100 persons, then in the ten textile finishing SIC codes the following percentages comprise small or medium sized firms (establishments):

PERCENTAGE OF ESTABLISHMENTS WITH $<100$ AND $>100$ EMPLOYEES

$\begin{array}{lll}2231 & 75.4 & 24.6 \\ 2251 & 68.9 & 31.1 \\ 2252 & 75.6 & 24.4 \\ 2257 & 71.6 & 28.4 \\ 2258 & 76.3 & 23.7 \\ 2261 & 80.3 & 19.7 \\ 2262 & 75.0 & 25.0 \\ 2269 & 80.3 & 19.7 \\ 2281 & 35.9 & 64.1 \\ 2295 & 84.9 & 15.1 \\ \text { TOTAL } & 72.4 & 27.6\end{array}$

SOURCE: CENSUS OF MANUFACTURES, 1987 
TABLE 9

TOTAL NUMBERS EMPLOYED IN TEXTILE FINISHING SIC CODES FOR THE UNITED STATES, 1987

\begin{tabular}{lllll}
\hline SIC CODES & ALL ESTABS & 1 TO 19 & 20 TO 99 & 100 AND OVER \\
& & & & \\
2231 & 118 & 50 & 39 & 29 \\
2251 & 161 & 68 & 43 & 50 \\
2252 & 426 & 150 & 172 & 104 \\
2257 & 334 & 124 & 115 & 95 \\
2258 & 241 & 82 & 102 & 57 \\
2261 & 218 & 113 & 62 & 43 \\
2262 & 268 & 145 & 56 & 67 \\
2269 & 183 & 89 & 58 & 36 \\
2281 & 414 & 63 & 86 & 265 \\
2295 & 186 & 94 & 64 & 28 \\
TOTAL & 2549 & 978 & 797 & 774 \\
\end{tabular}

SOURCE: 1987 CENSUS OF MANUFACTURES 
(Note: these figures are for the United States as a whole, but it is assumed that the numbers in each group are somewhat proportional at the New England regional level). Apart from SIC 2281, Yarn Mills, Except Wool, over 65 percent of establishments employ under 100 persons in all SIC codes. SIC 2295, Coated Fabrics, Not Rubberized, has the highest percent of its workforce employed in establishments with below 100 employees, with almost 85 percent in small or medium sized establishments. These figures support the assertion that the textile finishing industry is made up of relatively small firms. The textile finishing industry can thus be characterized as disintegrated, but agglomeration does not appear to be the factor that has influenced spatial location. Location, as stated previously is more a result of the original location of the industry as it grew up in New England from the late 1700 s on.

Lower Averaqe Wages Relative to Manufacturing as a Whole

The textile industry as a whole has lower wage levels relative to manufacturing. In 1980 textile wages represented 69.7 percent of the amount paid for all manufacturing wages. By 1989 this percentage had risen to 73.3 percent. Work hours however rose more slowly in textiles than in manufacturing as a whole, so total take home pay still lagged behind. 
Textile Eirms Seek Niches

In the face of increased competition, many textile firms are seeking market niches to insulate themselves from foreign competitors. Here they have advantages in the way they use their existing machinery to produce a superior product to the foreign import. The implications of this for flexible specialization are that we may well have identified a new dimension to the theory. Although few if any of the traits of flexibility under Piore and Sable have been identified, the flexibility in the use of machinery does provide a new, finer dimension to the basic theory.

\section{Conclusion}

This chapter has drawn conclusions about the occurrence of flexibility in textile finishing and has defined the type and degree of flexible specialization, if any, that is occurring. It has also characterized the textile finishing industry in New England in terms of the key areas that prevent it from being termed as flexibly specialized under Piore and Sabel's (1984) definition. 


\title{
CHAPTER 7
}

\section{FINDINGS OF THE INDUSTRY INTERVIEWS}

\begin{abstract}
This chapter summarizes the industry interviews that were conducted at three Rhode Island firms. The names of the companies have been changed to maintain confidentiality. At each interview, a predetermined format was used. Questions pertained to the company's history, production process, location, employees, customer/supplier relations, and perceptions of the future of the industry and the impact of imports.
\end{abstract}

\section{Company History}

At the $X$ Company the owner stated that there are only three to four vertically integrated companies left in the United States that still produce fabric from the beginning of the process through to the end (ie animal or plant through to the finished cloth). Company $x$ is one of these. Thirty three years ago the father of the current owner bought one third of the company. The original equipment is still used.

The ABC Company is one of the few totally integrated textile firms left in the country. Aside from buying wool from New Zealand and Australia, all the production to the finished product is carried out by the company.

The company was founded in 1919 in worcester, MA. The 
founders came from Bradford, England to the United States. In worcester they merged their textiles specialties of yarnmaking and fabric manufacturing. In the beginning they conducted their yarn and fabric business in two separate buildings in the worcester area.

As the business grew, a new plant was needed for the growing business. In 1929 the company moved to a larger facility in Rhode Island. The company remained there until 1939, when it moved to its present location. The company has grown to take up all five floors of the building, plus the adjacent yarn annex; a total of 550,000 square feet of space. In 1958 the company added a dye department, the weave department was expanded in 1965. In the 1970s yarn manufacturing capabilities were increased, and in 1988 a complete yarn preparation area and computerized material handling were introduced.

Today the company is one of the leading producers of fancy wool and wool-blended worsted fabrics.

The $Y$ Company used to have a plant in the South, but this closed down in 1978-79. Today the New England firm is more integrated than it has ever been.

\section{Production Process}

At the $\mathrm{X}$ firm, fabrics for home furnishings and wall coverings as well as apparel, are processed. The company processes materials such as wool, rayon, polyester, cotton, 
silk, and flax.

The mill performs sponging, whereby material is treated to prevent shrinkage. The processes used include high temperature steaming and cold water shrinking. The owner commented that the firm has the advantage over larger, more integrated companies because this is all it does, and therefore the company can provide a specialized service.

The cold water washing process used at the firm is continuous. Other processes carried out in the mill however, are batch operations.

At the $A B C$ Company, processes include top dying, package dying, and piece dying, weaving and spinning.

The $A B C$ Company is the leading U.S. firm in its industry and is known for its high quality fabrics.

The ABC Company is vertically integrated by necessity as there are very few firms that do the high grade work that the company requires.

The company still buys some yarn, although the overall trend is to further vertical integration as the market is too specialized and fancy. Much of the work has to be carried out in-house as the batches are too small to make it economical to be done outside. The Abc Company makes extensive use of technology. Many machines are computercontrolled, and there is very sophisticated materials handling. Finished products are customized for individual customers. The Company's latest innovation is the linkage, 
via computer network, of its designers' offices in New York with the production facilities in Rhode Island. A designer in New York can sit at a technical work station with a client, choose a fabric, and a sample of the finished product can be manufactured almost instantaneously.

The Y Company asserts that flexibility within the company has been desired for the last 10-15 years, from the time the world economy began to have an impact on the company .

Much of the industry is comprised of family-owned companies. The number of owners is small, and many owners have known each other and have done business the same way for years.

The equipment used by the $\mathrm{Y}$ Company is old but it carries out its own maintenance program, with a maintenance shop on-site. This is a very expensive part of total operation.

The company manages to stay ahead of foreign competition at this time due to the technologically advanced way it uses chemical processes. Alterations in this chemical process and methodology is what gives the firm competitive advantage, not getting new machinery. New machinery plays a relatively minor role.

The company has gravitated increasingly to the production of fabric for industrial sporting goods and away from fashion goods due to the violability of the latter 
market. For example the firm makes parachutes for the government which is a reliable product line. Diversification is the key to the firm's strategy to survival.

\section{Location}

The $\mathrm{X}$ Company was drawn to its present location because of its loading area and size. The owner would consider moving to Connecticut where incentives to business are good, if he didn't own the current site. He claims Rhode Island is a very expensive state to do business in. Workers compensation, taxes, high insurance, and health care costs are more expensive in Rhode Island relative to other states. The firm has moved to cost-sharing on health insurance.

Important locational considerations are satisfied by the current site's access to highways, quality of life in the state, and a large labor pool.

The city in which Company $X$ is located does not provide incentives to small businesses. The owner also talked of the problems he had experienced with the Department of Environmental Management and its constant queries regarding his business. He believes that both the city and state do not care whether businesses survive.

The ABC Company would prefer to be located in a one story building. There is no elevator in the current building. But the company has decided to live with the 
problem, as the cost of moving would be somewhere in the region of $\$ 4$ million.

\section{Employees}

The $\mathrm{X}$ firm is not unionized, and this the owner believes gives him greater flexibility in managing his employees. Other firms sub-contract to the company. The firm does not want a union as this would interfere with the current flexible policies.

Quality control is important to the business as it operates on a thin margin. Workers are employed for a forty hour work week. It is important that workers are responsible, reliable, and will stay with the company for a long period of time. The rationale here is that the longer they stay, the more operations they are capable of performing. Everyone in the company is expected to be capable of performing all the functions, although inevitably some are better at certain tasks than others. Many of the persons who work at the mill are recovering alcoholics, some are high-school dropouts, and some are illiterate. The skills required of the workers are patience to stay at a repetitive job for the whole day. New employees are expected to learn how to use three of the machines at the mill within three months of being hired. The type of prior experience that the owner looks for is any work related to the textile industry, as this shows that workers will know 
what to expect when they start the job. There is certain amount of hiring of younger family members of current employees.

In 1976 the ABC Company instituted a Employee stock Ownership Plan (ESOP), with limited shares available for employee ownership. Today, the company is $100 \%$ employee owned, after a previous chairman of the board sold his family's shares in the company.

According to management of the $A B C$ Company, it is easier to hire trained workers in the South, where working in the textile industry is treated as a profession, than the North where skilled labor is in shorter supply, workman compensation, taxes, and insurance costs are higher, and states do not help companies as they do in the south.

The company currently employs 550 workers. This is a reduction from the high of 750 in 1986. The company still runs three shifts despite the downturn.

The training period for a weaver is approximately eight weeks. To be able to work ten to twelve looms, it can take up to six months. This is the best paid of the nonmanagerial jobs. The training period for yarn spinning is six to eight weeks, and these workers are expected to be able to eventually work four frames. Today there are fewer people doing a wider range of jobs within the firm.

Openings usually occur in the off-shifts. There is a high turnover of staff, but this has been markedly less 
since the start of the economic downturn. With this

downturn, the company has been able to become much more picky in whom it hires. Fifty four percent of the workforce is comprised of minorities. This leads to both cultural and language problems.

The union system at Company $Y$ works on a two-tier basis of one wage for new employees, and a higher wage for older employees. Bottom tier wages are $\$ 8.00-\$ 10.50$, and top tier wages range from $\$ 9.60-\$ 10.50$.

A few years ago the company would hire anyone, but in today's tight market the personnel department likes to see a high-school diploma, to show that the person can stick at something.

In terms of future direction, the workforce needs to gain more motivation than it currently possesses. Fundamental changes in the attitude of the workforce need to occur. To this end, the company is introducing a profitsharing plan, and training people to show the importance of team effort. It is believed that workers should be included in the planning process to help avoid existing problems, and to utilize their specialist knowledge to develop new projects in a more successful way. The company also faces the problem that the industry does not attract smart, motivated people who want to work to improve the company. This change in attitude will require a change in the attitudes, not just of the people on the floor, but also of 
the foremen.

The workforce of Company $Y$ currently stands at 340 employees. This is down from 390. The company wishes to keep the current number, and offer overtime where necessary, rather than taking on extra staff. All the full-time workers have health insurance paid by the company.

In terms of flexibility of jobs done by the workers, all employees are hired to do a specific job. Some textile firms pay more to workers according to the number of jobs that they are able to perform. However, this is not the case at $Y$ Company, unless there is no alternative because a person is sick and the system would be unable to run without that operator.

\section{Customers/Suppliers}

Customers of the $\mathrm{X}$ Company are mainly located in the New York metropolitan area. Some are also located in New Bedford and Fall River, Massachusetts. The owner did not think local links were important. Nonetheless, being on the Eastern Seaboard is important, and the owner thinks parts of the textile industry will never go south, because New York remains the center of the garment industry.

The Y Company was bought out by one of its customers, who is a convertor. Today the parent company represents about $30 \%$ of the firm's business. With the parent company buying the company out, $30 \%$ of its business is guaranteed to 
them.

Customers are very small in number and familiar to the firm. The firm sells to convertors, who sell to the manufacturers. A convertor is in effect an integrator who owns the goods. Convertors arrange the different phases of the production process in disparate firms. Companies do not cross the commission-convertor line. The parent company is a convertor, and there is an unwritten code of ethics that the firms abide by, and that keep the firm's markets open by keeping individual convertors at arm's length.

Suppliers are local. The company tries to use local suppliers due to low transportation costs. The percentage of costs made up by transportation is less than in other industries. Such factors as the supply of materials is vital, for example, the firm had to shut down for a week due to no oil being available. However if the difference between two prices is minimal, the firm tries to always go with the local bidder.

\section{Future of the Industry and Imports}

The owner of $X$ Company does not predict any large amount of growth for the textile industry in the near future. He plans to continue to hire the same type of employee: illiterates rather than high school graduates and if anything would prefer to see more high school dropouts available for hire. 
Overseas competition does not really come from Japan, but there is a problem from other south-east Asian countries, such as Taiwan and Hong Kong. The Y Company manages to maintain its competitive edge in market niches due to: its technological advantage; access to dollar resources, and its ability to count on quick delivery time. Despite efforts at $\mathrm{Y}$ Company to remain in the market, the Plant Supervisor, when questioned, predicted that within the next five years, one of the major remaining firms in the region will go out of business, due to rising import competition and falling demand for services.

In terms of foreign competition company $Y$ tries to go with technologically strict product lines that require quick deliveries and offer nearby distribution centers.

The firm is increasingly faced with intense competition from countries such as Taiwan, where wages are so low that the firm has no choice but to back out of competition in that sector of the market. A major problem here is that a lot of the costs are perceived to come from having to meet strict environmental standards, which companies from the Far-East are not obliged to meet. 
CHAPTER 8

\section{CONCLUSIONS AND ROLICY IMPLICATIONS}

The United States enjoyed a position of international dominance in manufacturing after the second world War. Yet, the last twenty five years has seen the erosion of that position. The textile industry shows many of the woes of the rest of manufacturing: declining profits, reduction in employment within the industry, plant closings, and markets being eaten away by cheap imports. The loss of ground in many areas of manufacturing has prompted debate surrounding the reasons for the causes of declining economic performance. Some argue the present deterioration in economic performance results from the limits of the model of industrial development founded on mass production (Piore, Sabel, 1984). It is asserted that the most successful industries in the new global economy are those that are characterized by spatially dense networks of relatively small, vertically disintegrated firms. In other words, companies characterized by flexible specialization. This project addresses this debate by taking a systematically selected industry for a case study (textile finishing) and analyzing whether flexible specialization is occurring. The analysis uses both primary and secondary sources. Industry interviews with textile finishing firms in Rhode Island provide a first-hand picture of where the 
industry stands as we enter the 1990s. Secondary sources on the industry provided a broader base of information from which more general trends can be ascertained. Several characteristics and conclusions can be drawn about the textile finishing industry.

\section{Characteristics}

Total Employment

Total employment within textile finishing has declined since 1972. Employment in textile finishing in 1972 was 389.8 thousand. By 1987 this number had declined to 290.7 thousand. This represents a decrease of 34.1 percent. Due to stagnant demand, the industry is switching emphasis from increasing capacity to increasing efficiency.

This decline in textile jobs has severe implications for the workforce, much of which is being made redundant. Manufacturing jobs have traditionally paid a good wage to workers who are unskilled or semi-skilled. Manufacturing jobs are being replaced by service sector jobs paying lower wages. The implications of this provides a real problem which must be addressed.

Union membership in the textile industry has continued to decline since 1970 (Statistical Abstracts, 1990).

Further, the reason why wages in many service sector jobs are low is because they are non-unionized jobs. 
Rising Import Competition and Firm Size

The textile industry is suffering as a result of rising import competition. Rising import shares in the domestic market have led to a period of rethinking on the part of the U.S. textile industry. Consolidations have been rampant in many sections of the textile industry. Textile finishing, however, is somewhat different in organization. This segment of the larger industry is comprised of many small and medium sized firms. Figures from the 1987 Census of Manufactures reveal that 72.4 percent of all textile finishing firms have fewer than 100 employees. The finishing industry is thus highly disintegrated. Many of these small firms operate on a narrow profit margin, which puts them in a vulnerable position with rising import competition. At the interview with Company $Y$, this reality was brought home when the plant Supervisor offered the opinion that at least one of the five major textile finishers in the area will go out of business in the next five years as a direct result of increasing competition from abroad.

Lower Average Wages Relative to Manufacturing as a Whole Textile wages continued to be lower than manufacturing as a whole, although as a percentage of manufacturing wages the figure rose from 69.7 percent in 1980 to 73.3 percent in 1989. In the interview at Company $x$, the President stated 
the company paid its workers more if they knew more jobs. This allowed the firm greater flexibility with its workforce. If one worker did not come in on a given day, then another would be very available to fill in.

\section{Niche Production}

In an attempt to meet competition from imports, the textile finishing industry in New England is increasingly retreating from markets threatened imports, and seeking out niche markets where U.S. firms have an edge over imports.

Use of Machinery

In many cases the industry is using old dedicated machinery in innovative, flexible ways to produce different products. For example, at Company $Y$, one machine was used to dye two very different types of cloth, one plain, and one with a camouflage pattern. The literature on flexible specialization begins to address the issue of dedicated machinery, but does not go far enough. Walker (1990) points to the source of confusion over the misplaced emphasis on scale of output instead of production methods. He points out that one may get very long runs out of generalized machinery or short runs out of dedicated machinery, with corresponding effects on overall efficiency of labor and machine use, but the principles of mechanical improvement in each case are different. Walker raises an important issue 
but does not go far enough to emphasize the importance of looking more closely at dedicated machinery.

\section{Conclusions}

Because of the lack of agreement as to an exact definition of flexible specialization and what it encompasses, the question of whether flexible specialization is occurring in textile finishing in New England is a difficult one. However, based on the existing literature, and analysis from the information used in this project several conclusions can be drawn.

Textile Einishing as a Traditional Declining Industry

Textile finishing is a traditional industry, using old machinery. To the outsider, production methods appear to have changed little in fifty years. Employment in the industry has declined dramatically, and is continuing to do so. Management practices appear to be somewhat flexible and sensitive to the changes occurring within the industry. At Company $\mathrm{X}$, for example, the President took advantage of the absence of a union to practice flexible policies on allowing time off to workers.

Meeting the Challenges of the New Global Economy

The textile finishing industry is trying to face the changes that have occurred as a result of the globalization 
of business and trade. Because many of the firms are small they are unable to invest in the high-tech machinery that would provide greater flexibility. Also the face the problem of a tenuous market position and the lack of capital. Instead, they are making do with existing machinery and using it in innovative ways, thus injecting flexibility into dedicated machinery. The industry has also gotten rid of excess labor to improve its productivity and has shifted its emphasis from increasing capacity to increasing efficiency.

The Need for Further Study

This study uncovered a particular strategy for flexibility that the academic literature appears to have overlooked: the use of dedicated machinery in flexible ways. Research in this area would provide the industry with invaluable knowledge as to the relative gains such flexible practices could yield. Further, it would add an important component to the emerging definition of flexibility.

\section{Policy Implications}

It appears inevitable that jobs will continue to be lost in textile finishing in New England. Yet the existence of these jobs is crucial to many families who have worked in New England tertiles for generations. Indeed, the reason many of these workers' families came to the United States 
was to work in the mills. Loss of these jobs for semiskilled and unskilled workers has severe repercussions both for the workers and the state. Education programs may have to be provided to retrain workers, as most jobs today outside manufacturing require a minimum of a high school diploma. The minimum qualification stated by each of the three firms interviewed was a high school diploma, but each company stated that it did hire workers without a high school diploma when necessary. Indeed, at Company $x$, the President stated that what he needed most was more high school dropouts.

The ABC Company stated that 54 percent of its workforce was comprised of minorities. Many of these workers speak little, if any English. If these workers are to be integrated into service sector jobs requiring use of English language skills then language training will also need to be provided.

\section{Implications for Community Planning}

The implications of flexible specialization are profound for the profession of planning. In order to plan well one must have a thorough knowledge of the developments that shape the landscape. If the perception used to plan is one which is outdated, the plan that results will lead to failure. It is essential that all planners are aware of the impact that economic change, flexibly specialized or 
otherwise, has had and continues to have on the landscape.

\section{Planning Practice}

Planners in several areas of the world have integrated the theory of flexible specialization into their economic development policies. Examples include Barcelona, Spain where the road network has been built to provide networks between firms and encourage the growth of agglomeration. In Pennsylvania, Sabel has been involved in integrating flexible specialization into the state's economic development policy. Similarly, scott and storper are working with state government to establish an electric automobile industrial complex in Greater Los Angeles.

\section{Planning Methods}

The use of old methods (e.g. location quotients, shiftshare analysis) yield very shallow insights into what is occurring today. The old methods used to predict economic development strategies assume little if any change and are inappropriate for today's unstable situation. Further, the old methods are based on a theory of growth (investment and constant, but slow technological change) that is largely irrelevant today.

\section{Theory of Planning}

$$
\text { The transformation from fordism to flexible }
$$


accumulation is a profound and fundamental shift in the political economy. This shift has resulted, and will continue to result, in a change in the way that cities grow and develop. The emergence of flexible specialization and the impact that it has had on the way business is done highlights the fact that planners are actually not in control of the development process. Until we reach a stage where geographic industrialization is planned, cities will not be planned either.

In conclusion, it may take a national economic development strategy to provide the kind of planned economic development needed for the country to be able to continue to be competitive in the new global economy. A federally instigated economic development program might require overriding many of the powers given to states under the separation of powers. Loss of some control to the federal government may be a high price for the states to pay, but slipping into minor economic status in a New world order is a higher one. The issue must be addressed before the worst case scenario becomes reality. 


\section{BIBLIOGRAPHY}

Amin, Ash. 1989. Flexible Specialisation and Small Firms in Italy: Myths and Realities, Antipode, Oxford, Vol. 21, No. 1, April.

Burgy, J. Herbert. 1932. The New England Cotton Textile Industry: A Study in Industrial Geography", Waverly Press, Baltimore, MD.

Devino, w. Stanley. 1966. A Study of Textile Mill closings in Selected New England Communities, University of Maine Press, Maine.

Dillman, Donald A. 1978. Mail and Telephone Surveys: The Total Design Method, John Wiley \& Sons, New York.

Donaghu, Michael T. and Richard Barff. 1990. Nike Just Did It: International subcontracting and Flexibility in Athletic Footwear Production, Regional studies, Vol. 24, No. 6.

Feldman, Marshall M.A. and Huaqi Yuan. 1990. Industrial Organization and National Metropolitan Development, Paper presented at the ACSP 32 nd Annual Conference, Austin, Texas, November 2-4.

Gertler, Meric S. 1988. The Limits To Flexibility: Comments on the Post-Fordist Vision of Production and it's Geography, Department of Geography, University of Toronto, Toronto, Ontario, Canada.

Glashow, Robert A. President, Treasurer. 1990. Personal Interview, Woonsocket Sponging Inc., Woonsocket, RI, August 16.

Goddu, Robert. 1990. Personal Interview, Human Services, The Worcester Company, North Providence, RI, August 16.

Gordon, David M., Richard Edwards, Michael Reich. 1982. Segmented work, divided workers, Cambridge University Press, Cambridge, England.

Kane, Nancy Frances. 1988. Textiles in Transition:

Technology, Wages, and Industry Relocation in the U.S. Textile Industry, 1880-1930, Greenwood Press, Connecticut.

Kennedy, stephen Jay. 1936. Profits and Losses in textiles: Cotton Textile Financing Since the War, Harper and Brothers Publishers, New York.

Markusen, Ann. 1991. The Military Industrial Divide, Environment and Planning $D$ : Society and Space. 
Montgomery, James. 1968. A Practical Detail of the Cotton Manufacture of the United States of America; and the state of the cotton Manufacture of that country contrasted and compared with that of Great Britain, Johnson Reprint Company, New York.

New England Council, The. 1989. Directory of New England Manufacturers, 1989-1990, George D. Hall Co..

Olsen, Richard Paul. 1978. The Textile Industry, Lexington Books, D. C. Heath and Company.

Payne, Kenneth F. 1977. Early Rhode Island Textile Mill Villages: A Study of the origins and Examples of a Community Form, Unpublished Master's Thesis, University of Rhode Island.

Piore, Michael J. and Charles F. Sabel. 1984. The Second Industrial Divide: Possibilities for Prosperity, Basic Books, Inc., New York.

Plante, Robert. 1990. Personal Interview, Technical Director, Yarns, The worcester Company, North Providence, RI, August 16 .

Potter, M. David and Bernard P. Corbman. 1967. Textiles: Fiber to Fabric, McGraw-Hill Book Company, New York.

Rhode Island Strategic Development Commission. 1983. The Greenhouse Compact, Rhode Island Strategic Development Commission, Providence, RI.

Sabel, Charles. 1988. The Reemergence of Regional Economies, March.

Sayer, Andrew. 1988. Postfordism in question. Paper presented at the Annual Meetings of the Association of American Geographers, Phoenix, Arizona.

Schoenberger, E. 1988a. Multinational corporations and the New International Division of Labor:a critical appraisal, International Regional science Review 11, 105-119.

Schoenberger, E. 1988b. From Fordism to flexible accumulation: technology, competitive strategies, and international location, Environment and Planning D: Society and Space, Vol. 6, 245-262.

Scott, A. 1988. Flexible production systems and regional development: the rise of new industrial spaces in North America and Western Europe, International Journal of Urban and Regional Research 12, 2 June: 171-185.

Solo, R. 1935. Across the Industrial Divide: A Review 
Article, Journal of Economic Issues 19(3): 829-836.

Standard and Poors Industry Surveys. 1990. Textiles, Apparel, \& Home Finishings, Standard and Poor's Corporation, June, September.

Storper, Michael and Bennett Harrison. 1990 Flexibility, Hierarchy and Regional Development: The Changing Structure of Industrial Production systems and Their Forms of Governance in the 1990s, July.

Stout, Evelyn E. 1970 Introduction to Textiles, John Wiley \& Sons, Inc., New York.

Suarez, J. Luis. 1991 Personal Interview, Vice-President for Administration, Kenyon Industries, wakefield, RI, February 19.

United States Department of Commerce. 1987 Census of Manufactures, Dyeing and Finishing Textiles, U.S. Government Printing Office, Washington D.C..

United States Department of Commerce. 1990 Bureau of the Census, Statistical Abstract of the United States Government Printing office, Washington D.C..

Williams, K., T. Cutler, J. Williams, C. Haslam. 1987 The End of Mass Production?, Economy and Society, 16(3): p405439 .

Wood, S. 1990 The Transformation of Work?: Skill, flexibility and the labour process, Unwin Hyman, London. 